\title{
Overexploitation and cumulative drought trend effect on Ras El Ain karstic spring discharge (Khabour Sub-basin, Syria)
}

\author{
Boulos Abou ZaKhem* and Bassam KattaA \\ Geology Department, Atomic Energy Commission of Syria (AECS), Damascus, Syria. \\ *Corresponding author.e-mail: cscientific2@aec.org.sy
}

MS received 20 October 2016; revised 13 April 2017; accepted 17 April 2017; published online 6 October 2017

The effects of climate change and overexploitation are being strongly perceived in the studied area and the springs discharge is obviously affected. In this paper, Ras El Ain spring discharge and precipitation were analyzed by normalized methods on an yearly timescale. The deficit of Ras El Ain spring discharge due to overexploitation factors and drought effects was estimated. Cumulative drought analyses were carried out using SPI10 and SQI10. Finally, the decreasing trends of the spring discharge due to the deficiency in rainfall were analyzed. The main results reveal that the annual mean deficit of Ras El Ain spring discharge due to overpumping was between 32 and 45\%, whereas, annual mean deficit related to drought was between 22 and $35 \%$ on average, during the last 30 years (post-1984). The moving averages of SPI and SQI delineate very well the drought periods during last three decades. The cumulative droughts using SPI10 and SQI10 reveal that wet period (pre-1984) with positive values was characterized by high precipitation and spring discharge. Overexploitation period (1984-1989) is distinguished by decreasing SQI10 values whereas, SPI10 is almost stable. The response of the karst system to the precipitation signal has been changed, during the drought period (1990-2000), and the spring behaviour has been modified due to the first overexploitation period. Finally, overexploitation period (2001-2008) is related to the second phase of groundwater intensive pumping for irrigation purposes. Consequently, this period is completely catastrophic causing the drying up of the spring. The decreasing trends analyzed using DPI and DQI showed annual decreasing rates relative to the mean values of $-0.268 \%$ and $-0.105 \%$, respectively. Thus, the results of theoretical model reveal that precipitation will decrease by about DPI $=-20.7 \%$ and the discharge will decline by about $-9.2 \%$ by 2050 . Consequently, the declining discharge due to climatic variation under natural conditions as pre-1984 was about $10 \%$. Whereas, the catastrophic drying up of the spring was probably the consequence of the anthropogenic effects. Accordingly, it requires the development of sustainable water resources management program to reduce long-term drought risks, restore the groundwater reservoir and minimize the overexploitation effects on spring discharge.

Keywords. Time series analyses; standardized index; cumulative drought; overexploitation; Ras El Ain karstic spring; Syria.

\section{Introduction}

Overexploitation and climate change effects are being strongly perceived in the studied area where groundwater and springs discharge are clearly affected. Rain-fed agriculture in the Upper Khabour and floodplain irrigation by gravity along the Lower Khabour were replaced by groundwater 
irrigation. The main consequences are the complete drying up of the Ras El Ain spring due to groundwater depletion (UN-ESCWA and BGR 2013). In the studied area, water scarcity due to drought needs to be investigated with suitable approaches. Priority is given to identifying the relevant drought impacts and investigating the fundamental environmental, hydrologic, and socio-economic causes of these effects. This process is essential to decide on the specific mitigation arrangements that can be implemented to reduce short and long-term drought and overexploitation risks. To realize better management of drought phenomena, which make water scarce due to drought, very different from those caused by aridity, we need to understand the characteristics and consequences of these droughts.

\subsection{Hydrology and climate of the study area}

The studied area is located in the Upper Khabour Sub-basin (so called Upper Jezireh Basin) in Syria. The Khabour Sub-basin is shared by Syria and Turkey, with a small part of the basin in Iraq. The drainage basin covers a surface area of almost $36,200 \mathrm{~km}^{2}$, of which $28 \%$ lies in Turkey and $66 \%$ in Syria (figure 1). The Khabour River, which forms the largest tributary of the Euphrates River, has a total length of $388 \mathrm{~km}$ of which $308 \mathrm{~km}$ lie in Syria. After the river crosses the SyrianTurkish border, the stream receives substantial input from several major karstic springs near Ras El Ain town. The estimated average discharge of Khabour River during the period 1943-1961 was $45 \mathrm{~m}^{3} / \mathrm{s}$ in Tel Tamer station (Burdon and Safadi 1963; UNDP-FAO 1966; Kattan 2001; ALCharideh and Abou Zakhem 2009). During the period 1961-1980, the mean annual discharge values ranging from $46.9 \mathrm{~m}^{3} / \mathrm{s}$ at Ras El Ain near the Syrian-Turkish border, to $67.2 \mathrm{~m}^{3} / \mathrm{s}$ at Hassakha after the confluence of all Khabour tributaries. Discharge at the Ras El Ain spring, one of the largest karst springs in the world, declined from an annual mean discharge of $40 \mathrm{~m}^{3} / \mathrm{s}$ in 1980 to only $14 \mathrm{~m}^{3} / \mathrm{s}$ in 1998 and $7.38 \mathrm{~m}^{3} / \mathrm{s}$ in 2003 (FAO 2009; Hole 2009; UN-ESCWA and BGR 2013). This decline has been widely attributed to the overexploitation of groundwater for irrigation purposes in the catchment areas. The discharge of the Khabour River in Syria at Ras El Ain between 2008 and 2010 was between 2.09 and $3.6 \mathrm{~m}^{3} / \mathrm{s}$, less than $5-10 \%$ of the natural pre-1980 values (table 1 ).
The Khabour Sub-basin is characterized by a Mediterranean climate with dry, hot summers and wet, cool winters. From north to south, yearly precipitation decreases from more than $800 \mathrm{~mm}$ in the mountainous regions to less than $300 \mathrm{~mm}$. A mean annual precipitation of $450 \mathrm{~mm}$ may be assumed for the catchment areas and the mean annual potential evaporation is about 1000-1300 mm (UN-ESCWA and BGR 2013).

The Paleogene (Middle to Upper Eocene) carbonate formation constitutes the main karstic limestone aquifer system of the Khabour Subbasin. This aquifer outcrops in Mardin uplift and Anatolian mountain chain at $>1000$ m ASL (Turkish side), while is covered by low permeable, Neogene and Quaternary sediments in the border area between Syria and Turkey at 200-400 m ASL. The lower boundary of the aquifer system consists of an aquitard of marls and marly limestone of Upper Cretaceous (Maastrichtian) to Paleocene age, which is found at great depth $(1200 \mathrm{~m})$. The thickness of the Jezireh Tertiary Limestone Aquifer System is usually around $200-300 \mathrm{~m}$ in Turkey. While in Syria, it generally increases towards the south and east to more than $550 \mathrm{~m}$. This aquifer is unconfined and shallow on the Turkish side to become locally unconfined near the border and completely confined and deeper towards the southern part of the basin, with artesian spring discharge on the Syrian side. The large discharge water volumes from the aquifer in some springs indicate high transmissivities in the karstic system (3 and $4 \mathrm{~m}^{2} / \mathrm{s}$ ) around the group of springs. The volume of water stored in the aquifer system of the Ras El Ain spring has been calculated as 7400 MCM or the equivalent of 6 years of discharge at the average natural rate. The catchment of the Ras El Ain spring is mainly located in Turkey. It was concluded that a recharge area of $8100 \mathrm{~km}^{2}$ is required to replenish the annual discharge of the Ras El Ain spring, which was calculated at an average of $1219 \mathrm{MCM} / \mathrm{y}$ (150 mm of average effective recharge). Agriculture development during the last few decades in the Khabour Sub-basin, especially the cultivation of cotton and wheat has increased the demand on groundwater for irrigation use. The irrigated land in the study area increased eight-fold from 7400 to 65,000 ha between 1990 and 2000 . Whereas, the total irrigated land reached 358,000 ha, of which about 313,000 ha were irrigated by wells in 2010. The total abstraction was estimated to be around 138 and 159 BCM in Turkish and Syrian sides, respectively (UN-ESCWA and BGR 


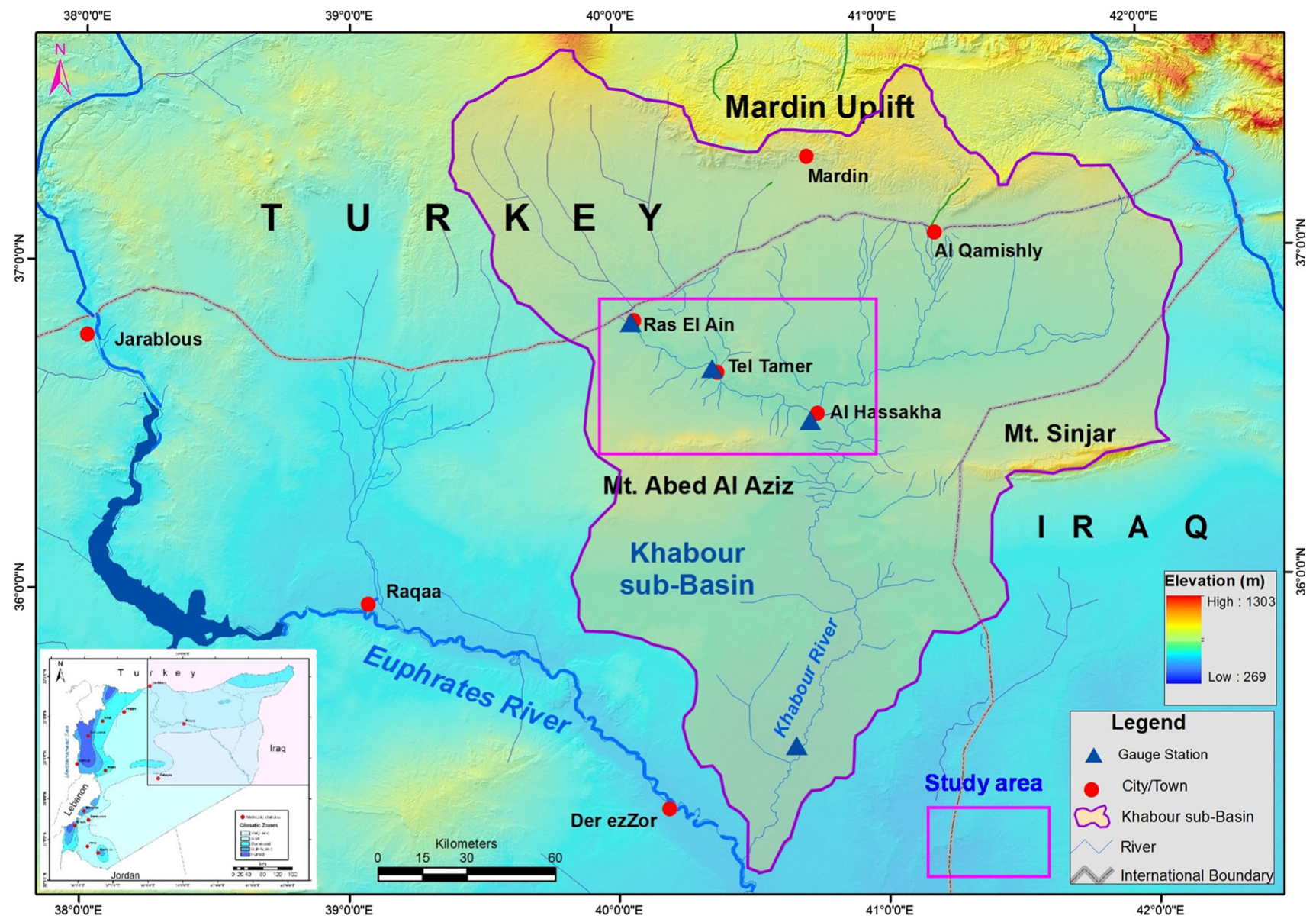

Figure 1. The topographic map of the study area (Upper Khabour Sub-basin).

Table 1. Mean annual discharge of Ras El Ain spring $\left(\mathrm{m}^{3} / \mathrm{s}\right)$.

\begin{tabular}{lcr}
\hline Years & $Q\left(\mathrm{~m}^{3} / \mathrm{s}\right)$ & $(\%)^{*}$ \\
\hline $1961-1980$ & 46.9 & 100 \\
$1981-2000$ & 25.8 & 55 \\
2003 & 7.38 & 16 \\
2008 & 3.6 & 8 \\
2009 & 4.3 & 9 \\
2010 & 2.09 & 4 \\
\hline
\end{tabular}

* Is relative to $Q$ pre- 1980 in $\%$.

2013). Consequently, the total discharge of the karst springs in the Khabour Sub-basin, especially in the Ras El Ain karst system has substantially decreased.

Climate models project increased aridity in the 21st century over most of Africa, southern Europe, and the Middle East (Dai 2011). The Mediterranean regions are becoming hotter and drier due to climatic change effect by global warming.
The climate change scenarios for 2050 predict a reduction in precipitation between 15 and $25 \%$ and increase in temperature between 1.5 and $2.75^{\circ} \mathrm{C}$. Subsequently, the expected negative impact would be a reduction in water resources both in terms of water availability and spring discharges (Ragab and Hamdy 2004; IPCC 2007). The percentage of time with moderate, severe and extreme drought is expected to increase strongly in the southeastern Mediterranean region (Törnros and Menzel 2014). The technical definition allows for the identification of onset and end as well as the degree of severity of a drought.

\subsection{Drought definition}

Drought is a temporary deviation within the normal variability and can be considered an insidious hazard of nature. It occurs in virtually all climatic zones, while aridity is a permanent feature of climate. Drought is a relative, rather than an absolute condition that should be defined for each 
region. Droughts can vary in intensity, duration, and spatial extent. Droughts have been classified by type as follows (Wilhite and Glantz 1987; Hamdy 2004; MED WS and D WG 2007).

\subsubsection{Meteorological drought}

This is defined as the deficiency of precipitation over a large area and usually measured for the long-term record. In the study area, the regional severe drought between 1998 and 2001 could also explain the reduction in flows during this period. Since 1999, the lower Khabour reportedly runs dry in July and August (Zaitchik et al. 2002).

\subsubsection{Agricultural drought}

This is concerned specifically with the effects of water scarcities on crops and grasses and other forages. Agriculture is usually the first sector to experience the devastating effects of drought. Therefore, agricultural drought is most closely associated with deficiencies that occur in soil moisture and lead to losses in yield. Rain-fed agriculture in the Upper Khabour was increasingly replaced by groundwater irrigation. This radical change was related to the precipitation shortfall and the development of agriculture projects based on groundwater pumping (Zaitchik et al. 2002).

\subsubsection{Hydrological droughts}

These refer to deficiencies in surface and subsurface water supplies. This drought is directly measured as stream flow, lake, reservoir and groundwater levels, and as spring discharge. Hydrological measurements are not the earliest indicators of drought, because there is a time lag between the time of precipitation and its appearance in the drainage network. Groundwater is the last to be affected by drought during its beginning; it is the last to experience a return to normal water supply levels. Obviously, the length of the recovery period is a function of the intensity and duration of the drought, and the precipitation amount received after the drought period (Wilhite and Glantz 1987; Hamdy 2004; MED WS and D WG 2007).

\subsubsection{Groundwater drought}

This is a new concept presented by Mishra and Singh (2010), which highlights the understanding of complicated hydrogeological processes with respect to the change in dynamics of hydrometeorological variables with changes in land cover. The large volume of spring water discharged from the aquifer system in the Ras El Ain area has been dramatically reduced as the groundwater level dropped due to heavy groundwater overexploitation. Groundwater levels have dropped at an average rate of $1.68 \mathrm{~m} / \mathrm{y}$ during 1999-2003 in the Ras El Ain area (ACSAD et al. 2003). Consequently, the karstic system was considered under severe groundwater drought.

Karst aquifers operate as large natural reservoirs of precipitation, and spring discharges reflect wet and dry periods, as well as long-term climate change (Chen et al. 2004; Fiorillo et al. 2007; Smith and Hunt 2010). Prolonged periods of precipitation deficits can reduce the response of the spring discharge and cause drought of karst system and in some cases drying up completely causing the collapse of sensitive part of the karst and modification of spring behaviour (Fiorillo 2009). The Standardized Precipitation Index (SPI) has been widely used to characterize meteorological drought and has recently been recommended by the WMO as an optimal index to characterize meteorological droughts (WMO 2012). Moreover, due to the useful advantages of the SPI approach to drought characterization (McKee et al. 1993), it 'could be applied in a similar manner to precipitation, snow-pack, stream flow reservoir storage, soil moisture, and groundwater'. The SPI methodology has been applied in hydrological time series to characterize aspects of hydrological droughts. For example, reservoir storage (Vicente-Serrano and López-Moreno 2005), runoff (Shulka and Wood 2008), soil moisture (Sheffield and Wood 2008; Sheffield et al. 2009), Standardized Discharge Index (SQI) (Fiorillo and Guadagno 2010, 2012; Fiorillo et al. 2014), groundwater drought analysis using Standardized Groundwater Level Index (SGLI) and SPI (Bloomfield and Marchant 2013), Decreasing Precipitation and Discharge Indices (DPI\%) and (DQI\%) (Abou Zakhem and Kattaa 2016a). Several studies were carried out in the Mediterranean region using SPI (Loukas and Vasiliades 2004; Vicente-Serrano et al. 2004; Cancelliere et al. 2005, 2006; Hajispyrou et al. 2007; Michaelides and Pashiardis 2008; Pashiardis and Michaelides 2008; Turgu 2008).

Groundwater overexploitation is produced when the abstraction exceeds the natural recharge rate of the aquifers. The vulnerability of an aquifer to overexploitation depends on its type, climate, 
hydrological conditions, and the water uses. The rapid expansion in groundwater abstraction over the past 30-40 years has supported new agricultural project development in regions, where alternative surface water resources are insufficient to meet the increasing demand (Zaitchik et al. 2002; Hole 2009; UN-ESCWA and BGR 2013). Overabstraction leads to groundwater depletion, with consequences like desertification, deterioration of water quality (e.g., saltwater intrusion), modification of groundwater and surface water interactions, land subsidence, collapse of sensitive part of the karst aquifer and spring discharge depletion or completely drying up (MED WS and D WG 2007; El-Hakim and Bakalowicz 2007).

The objective of the present paper is to study the precipitation of Ras El Ain and Tal Tamer meteoric stations, the meteorological drought characteristics using SPI and comparing this with the hydrological drought of Ras El Ain spring discharge, Tal Tamer and Al Hassakha gauge stations using SQI. Cumulative drought analyses were carried out using SPI10 and SQI10. Assessment of the annual mean deficit of Ras El Ain spring discharge due to overexploitation of groundwater in the catchment areas and that caused by drought was carried out by long-time series analyses. The decreasing trends of the spring discharge due to the decrease in rainfall were analyzed using DPI and DQI. Finally, the proposed theoretical model provides an assumption of the discharge mean values of the Ra El Ain spring with or without minimum anthropogenic factors as pre-1984 on the catchment areas for 2050 .

\section{Materials and methods}

\subsection{Standardized index}

\subsubsection{Standardized precipitation index (SPI)}

SPI is an index based on the probability of precipitation and can be calculated for different time scale, which allows it to be useful for both short-term agricultural and long-term hydrological applications. Soil moisture conditions respond to precipitation anomalies on a relatively short time scale, while shallow groundwater and karstic system reflect the longer-term precipitation irregularities (Hamdy 2004; MED WS and D WG 2007). The assessment of drought severity and early warning of drought can be provided by the SPI. The
SPI is particularly appropriate to compare drought conditions among different time scales and different climatic zones, because of its standardization characteristics (Bonaccorso et al. 2003; Hamdy 2004). The SPI is an optimal index for drought risk analysis due to its intrinsic probabilistic characters (Guttman 1999). The SPI has been widely applied (McKee et al. 1995; Heim 2000; Rossi and Cancelliere 2002; Hayes et al. 2005). The computation of SPI is based on the long-term precipitation record for any location and desired period. This long-term record is fitted to a probability distribution such as gamma distribution, which is then transformed into a normal distribution so that the mean SPI is zero, hence wet and dry climates can be monitored (Edwards and McKee 1997). The SPI is defined by the following equation (McKee et al. 1993; VicenteSerrano et al. 2004; Fiorillo et al. 2014):

$$
\mathrm{SPI}=\frac{P i-m}{\sigma}
$$

where $P i$ is the precipitation in year $i, m$ is the long-term mean annual precipitation and $\sigma$ is the standard deviation.

The SPI is a dimensionless index where negative values indicate drought and positive values indicate wet conditions. Drought intensity, magnitude and duration can be determined as well as the climatic classification with the probabilities of occurrence and $\Delta P \%$ can be determined, using the SPI (Cancelliere et al. 2006; table 2).

\subsubsection{Standardized discharge index (SQI)}

Discharge time series of karst springs can be treated in the same way. The SQI is defined by the following equation:

$$
\mathrm{SQI}=\frac{Q i-m}{\sigma}
$$

where $Q i$ is the discharge in year $i, m$ is the longterm mean annual discharge and $\sigma$ is the standard deviation. Because the SQI is normalized, high and low water years can be represented in the same way. Wet and dry periods can also be monitored using the SPI and SQI (Fiorillo et al. 2014). The standardized values allow comparing karst springs characterized by different discharge magnitudes; independently from trends and periodicity existing in the time series, standardized plot simply allows distinguishing periods of lower or higher than average flow, and highlights the extreme values. However, the lowest values of the rainfall, 
Table 2. Wet and drought period classification according to the SPI index.

\begin{tabular}{lllr}
\hline Index value & \multicolumn{1}{c}{ Class } & Probability & $\Delta P(\%)$ \\
\hline $2 \leq \mathrm{SPI}$ & Extremely wet & $0.977-1.000$ & 2.3 \\
$1.5 \leq \mathrm{SPI}<2$ & Very wet & $0.933-0.977$ & 4.4 \\
$1 \leq \mathrm{SPI}<1.5$ & Moderately wet & $0.841-0.933$ & 9.2 \\
$-1 \leq \mathrm{SPI}<1$ & Near normal & $0.159-0.841$ & 68.3 \\
$-1.5 \leq \mathrm{SPI}<-1$ & Moderate drought & $0.067-0.159$ & 9.2 \\
$-2 \leq \mathrm{SPI}<-1.5$ & Severe drought & $0.023-0.067$ & 4.4 \\
$\mathrm{SPI}<-2$ & Extreme drought & $0.000-0.023$ & 2.3 \\
\hline
\end{tabular}

causing the most intense droughts in the spring discharge series, are well recognizable (Fiorillo and Guadagno 2012).

\subsection{Cumulative drought analyses}

\subsubsection{Standardized precipitation (SPI10) and discharge (SQI10) index}

Precipitation time series is generally aggregated for several months (SPI- $n, n=1,2, \ldots, 36$ and 48) that can be found in the publications. The SPI (3 months) is used for a short-term or seasonal drought index; SPI (12 months) is used for an intermediate-term drought index, and SPI (48 months) is used for a long-term drought index (Edwards and McKee 1997). In our study, 1st SPI was computed for annual precipitation (12 months) related to the yearly hydrological cycle. Whereas, the cumulative drought index was estimated for SPI over 10 years (120 months) related to decadal drought. The SPI10 is defined as the balance of SPI over 10 years representing the short hydrogeologic cycle, which constitutes the recent recharge of karstic and shallow groundwater. The SPI10 is directly computed by the same method of SPI (SPI10 = SPI 120 months; Edwards and McKee 1997). Consequently, the cumulative standardized discharge index (SQI10) has similar classification and probabilities of occurrence as SPI (table 2).

\subsection{Precipitation and discharge decreasing trends}

\subsubsection{Decreasing precipitation DPI and discharge $D Q I \%$ index}

Decreasing precipitation index (DPI) is the relative deviation of precipitation compared to the long-term mean value. The DPI laid the foundation for the establishment of criteria for years and seasons to identify given periods as extremely dry or humid, where negative values indicate drought and positive values indicate wet conditions. The application of the DPI when attempting to establish how much rainfall a certain month received (whether there was an abundance or deficiency) is discussed in many papers (Zurek 2007; Labedzki and Bak 2014). The DPI was calculated as follows:

$$
\mathrm{DPI}=\left(\frac{P i-m}{m}\right) \times 100
$$

where DPI is decreasing precipitation index for the year $i(\%) ; P i$ is the precipitation of year $i$, and $m$ is the long-term mean annual precipitation.

Discharge time series of karst springs can be treated in the same way. Decreasing discharge index (DQI) is defined as the relative deviation of the discharge $(Q i)$ of year $i$ from the long-term mean $(m)$ of the series to this mean:

$$
\mathrm{DQI}=100 \times \frac{(Q i-m)}{m} .
$$

\section{Results and discussion}

\subsection{Precipitation time series}

The study is based on the annual precipitation data of Ras El Ain and Tal Tamer meteoric stations, available from $1940-1941$ to $2007-2008$ ( $n=68$ y). The long-term mean annual precipitation of Ras El Ain is $m=296.9 \mathrm{~mm}$, the confidence level at $95 \%$ of this mean is $\pm 18.8 \mathrm{~mm}$, the standard deviation is $\sigma=77.7 \mathrm{~mm}$ and coefficient of variation $C V=0.26$. The minimum is $170.7 \mathrm{~mm}$ in 1969-1970 and the maximum is $596.9 \mathrm{~mm}$ in 
1968-1969. The mean annual precipitation of Tal Tamer is $m=244.2 \mathrm{~mm}$, the confidence level at $95 \%$ of this mean is $\pm 16.8 \mathrm{~mm}$, the standard deviation is $\sigma=69.5 \mathrm{~mm}$ and coefficient of variation $C V=0.29$. The minimum is $124 \mathrm{~mm}$ in $1999-2000$ and the maximum is $439.3 \mathrm{~mm}$ in 1968 1969, median, 1st and 3rd quartile are shown in table 3 .

It is observed that the precipitations at Ras El Ain and Tal Tamer are almost parallel and have the same variation patterns. The precipitation amounts are generally decreased by about $18 \%$ from Ras El Ain towards the south at only $35 \mathrm{~km}$ in Tal Tamer meteoric station. The long-term annual precipitation of Ras El Ain and Tal Tamer meteoric stations is shown in figure 2 .

Table 3. Descriptive statistics of precipitation ( $\mathrm{mm}$ ) of Ras El Ain and Tal Tamer meteoric stations.

\begin{tabular}{lll}
\hline & Ras El Ain & Tal Tamer \\
\hline Mean $(m)$ & 296.9 & 244.2 \\
St. dev. $(\sigma)$ & 77.7 & 69.5 \\
Minimum & 170.7 & 124.0 \\
1st quartile & 259.8 & 203.7 \\
Median & 284.0 & 233.5 \\
3rd quartile & 331.7 & 287.8 \\
Maximum & 596.9 & 439.3 \\
CV $(\sigma / m)$ & 0.26 & 0.29 \\
Count $(n)$ & 68 & 68 \\
Confidence level $(95 \%)$ & 18.8 & 16.8 \\
\hline
\end{tabular}

The relationship between annual precipitation of Ras El Ain and Tal Tamer meteoric stations demonstrates a good correlation coefficient $(R=$ 0.822 ) as follows (figure 3a):

$$
\begin{aligned}
\text { Ras El Ain } & =0.9493 \mathrm{Tal} \text { Tamer }+65.138 \\
R^{2} & =0.676
\end{aligned}
$$

This equation is used to reconstruct some missing data in these meteoric stations. To analyze the precipitation time series of these stations, the annual mean is computed over 30 yrs, which is the current normal period as suggested by the World Meteorological Organization (WMO) to be statistically representative. The results demonstrate a decreasing trend of about $-0.86 \mathrm{~mm}$ per year at these stations (figure $3 \mathrm{~b}$ ). Consequently, the decreasing amount of the annual mean precipitation over 30 years (1970-2000) is about $26.1 \mathrm{~mm}(8 \%)$ at Ras El Ain and $25.8 \mathrm{~mm}$ $(10 \%)$ at Tal Tamer meteoric stations. Comparing the mean precipitation over past 30 years at Ras El Ain, Tal Tamer to Damascus meteoric station (Abou Zakhem and Kattaa 2016a, b) computed for 1970-2000 reveal that the decreasing trend of Damascus precipitation is about $-1.2 \mathrm{~mm}$ per year and the decreasing amount of the annual mean precipitation over 30 yrs is about $37 \mathrm{~mm}$ (17\%). This indicates that the drought effect is a slow phenomenon well observed in the region during the last 30 yrs. However,

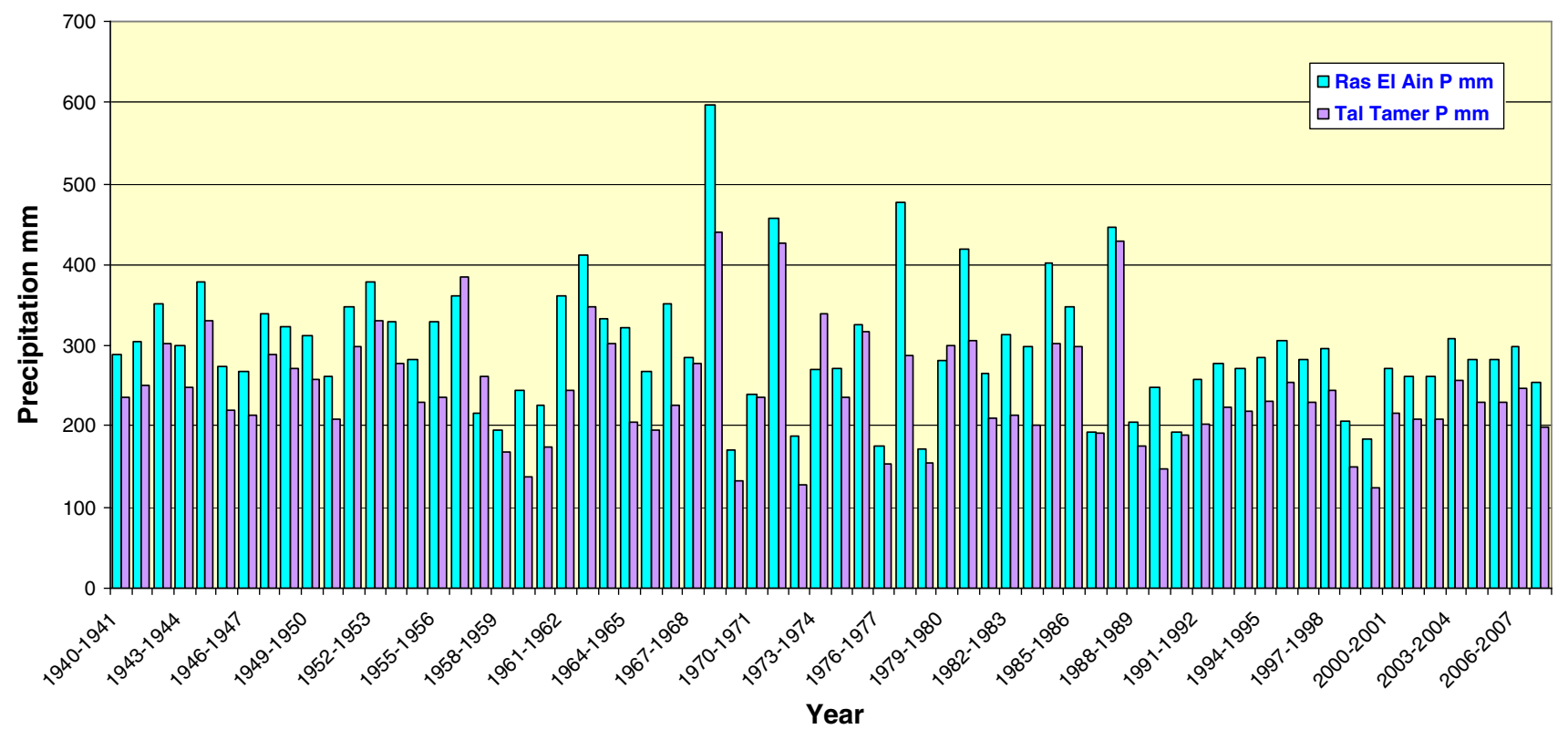

Figure 2. Annual precipitation in Ras El Ain and Tal Tamer meteoric stations. 

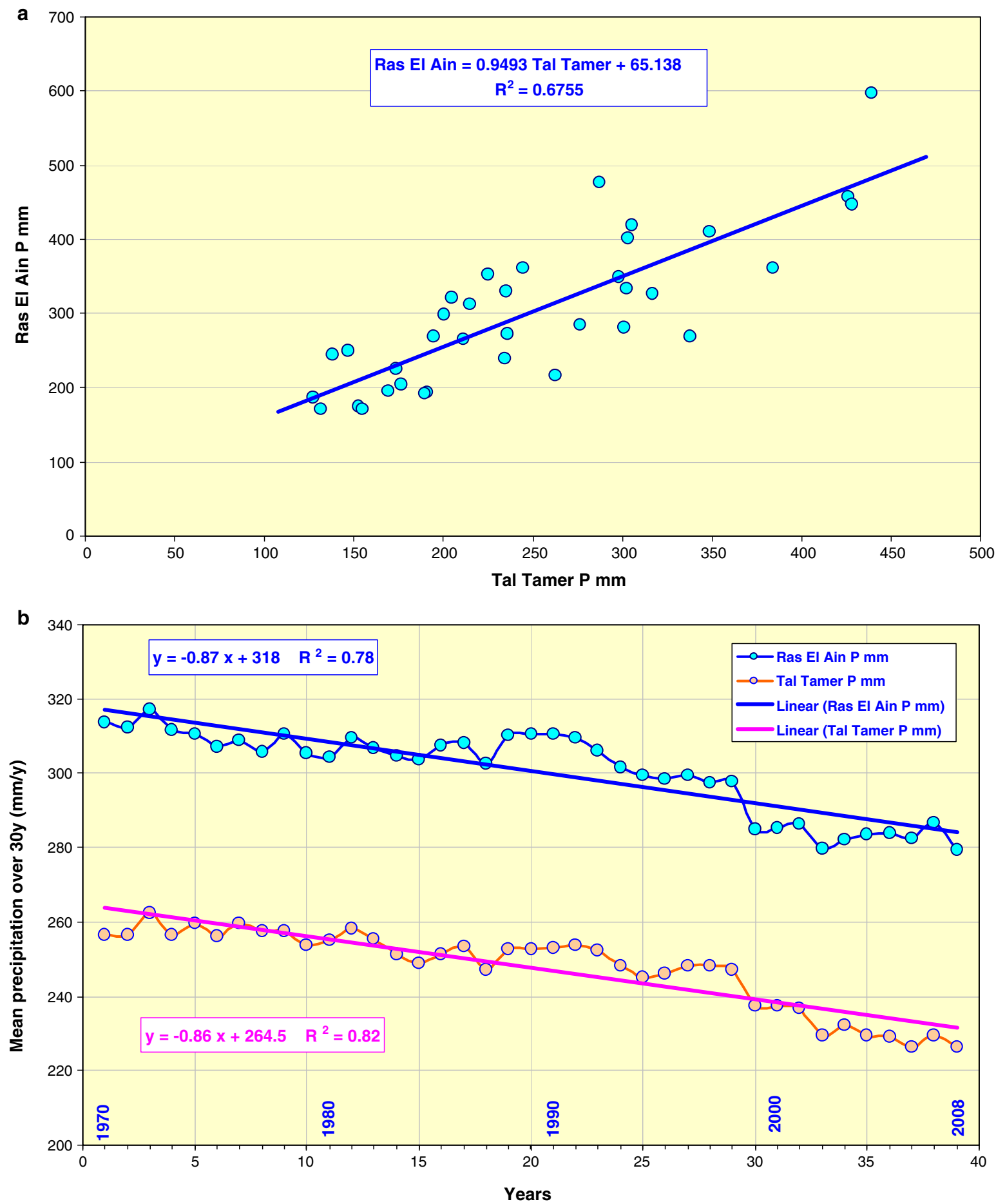

Figure 3. (a) The relationship between annual precipitations. (b) Annual mean precipitation over 30 yrs at Ras El Ain and Tal Tamer meteoric stations.

drought severity is more pronounced in Damascus basin compared to Ras El Ain area. Thus, the climate of these regions is continental arid to semi-arid and representative of eastern Mediterranean region which is vulnerable and prone to severe drought experienced during the last three decades.

\subsection{Discharge time series}

Monthly mean discharge time series (1942-1943 to 2003-2004) of 62 yrs of Ras El Ain spring gauge station is shown in figure 4(a). Average monthly discharge in February during this time series was $44.6 \mathrm{~m}^{3} / \mathrm{s}$, whereas, this average decreases to 
$31.4 \mathrm{~m}^{3} / \mathrm{s}$ in August. The maximum monthly mean discharge was measured in February in 1953-1954 reaching $103.8 \mathrm{~m}^{3} / \mathrm{s}$. While the minimum monthly mean discharge of $0 \mathrm{~m}^{3} / \mathrm{s}$ was recorded in April for the first time in 2000. It is observed that there is a decrease of monthly mean discharge between 1958 and 1966 followed by an increase from 1968 to 1981. After 1984, it displayed a slow decline (figure 4a). The annual mean discharge time series from 1942-1943 to 2013-2014 (72 yrs) of Ras El Ain karstic spring was analyzed. The long-term annual mean discharge is $m=32.7 \mathrm{~m}^{3} / \mathrm{s}$, the confidence level at $95 \%$ of this mean is $\pm 4 \mathrm{~m}^{3} / \mathrm{s}( \pm 12.2 \%)$, the standard deviation is $\sigma=17.1 \mathrm{~m}^{3} / \mathrm{s}$ and coefficient of variation $C V=0.52$. The minimum discharge was recorded in 1999-2000 for the first time $0.04 \mathrm{~m}^{3} / \mathrm{s}$ and the maximum was measured in 1953-1954 reaching $55.4 \mathrm{~m}^{3} / \mathrm{s}$. Support pumping of about $3 \mathrm{~m}^{3} / \mathrm{s}$ for irrigation purposes was launched in 1999-2000 during the dry season. The polynomial line of 4 th degree illustrates very well the inter-annual smoothing variations of annual mean discharge. It is observed that the annual discharge is decreased during the famous drought of the 50's, which affected the eastern Mediterranean regions (Abou Zakhem and Kattaa 2016a, b). Whereas, a very net increase of annual mean discharge covering the 70's to the middle of the 80 's. The successive decrease of annual mean discharge was recorded from the middle of the 80's to 2000 . The support pumping does not represent significant difference at annual discharge scale. Prevailing drought periods since the 80's of the last century combined with overexploitation of the surrounding groundwater have led to a catastrophic decline of spring discharge causing complete drying up of the major karstic spring of Ras El Ain in 2014 (figure 4b).

\subsubsection{Discharge time series analyses}

The annual mean discharge time series from $1942-1943$ to $2013-2014$ ( $n=72$ yrs) of Ras El Ain, Tal Tamer, and Al Hassakha gauge stations are presented in figure 5. The time series of these three stations are generally parallel and present similar variation patterns. Thus, the three gauge stations represent the output signals of the regional groundwater complex aquifer of Khabour Sub-basin. Decreasing trend and the differences between the discharge amounts of these stations are more pronounced after the second half of the
80 's. Hence, these time series can clearly be divided into two parts as follows (figure 5):

1. Pre-1984 period which represents natural variation patterns with high water years during 1953-1954, 1962-1963 and 1968-1969, followed by a slight decrease due to moderate drought periods during 1960-1961, 1965-1966 and 19761977. The sequences of wet and dry years demonstrate that the precipitation signal input is well expressed. The annual mean discharges during this period were $45.2,49$ and $46.5 \mathrm{~m}^{3} / \mathrm{s}$, at Ras El Ain, Tal Tamer and Al Hassakha gauge stations, respectively.

2. Post-1984 period is characterized by an unexpected decrease of discharge for 3-5 consecutive dry years separated by one wet year only (1987-1988). The decreasing trends persisted to drop reaching minimum discharge amount after 2000 to 2014 . During the post-1984 period, the annual mean discharges were 15.2, 10.8 and $9.9 \mathrm{~m}^{3} / \mathrm{s}$ in the three respective stations. The signal of input function effect of annual precipitation is completely hidden. Consequently, the anthropogenic effect represented by overexploitation of groundwater is more pronounced which occurred during this period.

\subsection{Reconstructed annual mean discharge of Ras El Ain spring}

\subsubsection{Relationship between annual mean discharges at the gauge stations}

The relationship between annual mean discharge time series (1943-2014) of Ras El Ain, Tal Tamer, and Al Hassakha gauge stations is illustrated in figure $6(\mathrm{a}, \mathrm{b})$. The correlation coefficients $(R=$ 0.95 and 0.96$)$ are generally high and exhibits good relationship between the discharges in these gauge stations. It is believed that the proportional decrease of discharge in these stations is generally related to the climatic effects, which are considered as regional phenomena. While, disproportional discharge decrease among these stations is attributed to anthropogenic effects in Khabour Sub-basin. The correlation between annual mean discharge (1943-1990) of Ras El Ain and Tal Tamer gauge stations is expressed by the following equation:

$$
\begin{aligned}
& \text { Tal Tamer }\left(Q \mathrm{~m}^{3} / \mathrm{s}\right) \\
& =2.06 \text { Ras El Ain }\left(Q \mathrm{~m}^{3} / \mathrm{s}\right)-43.9, \\
& R^{2}=0.90
\end{aligned}
$$



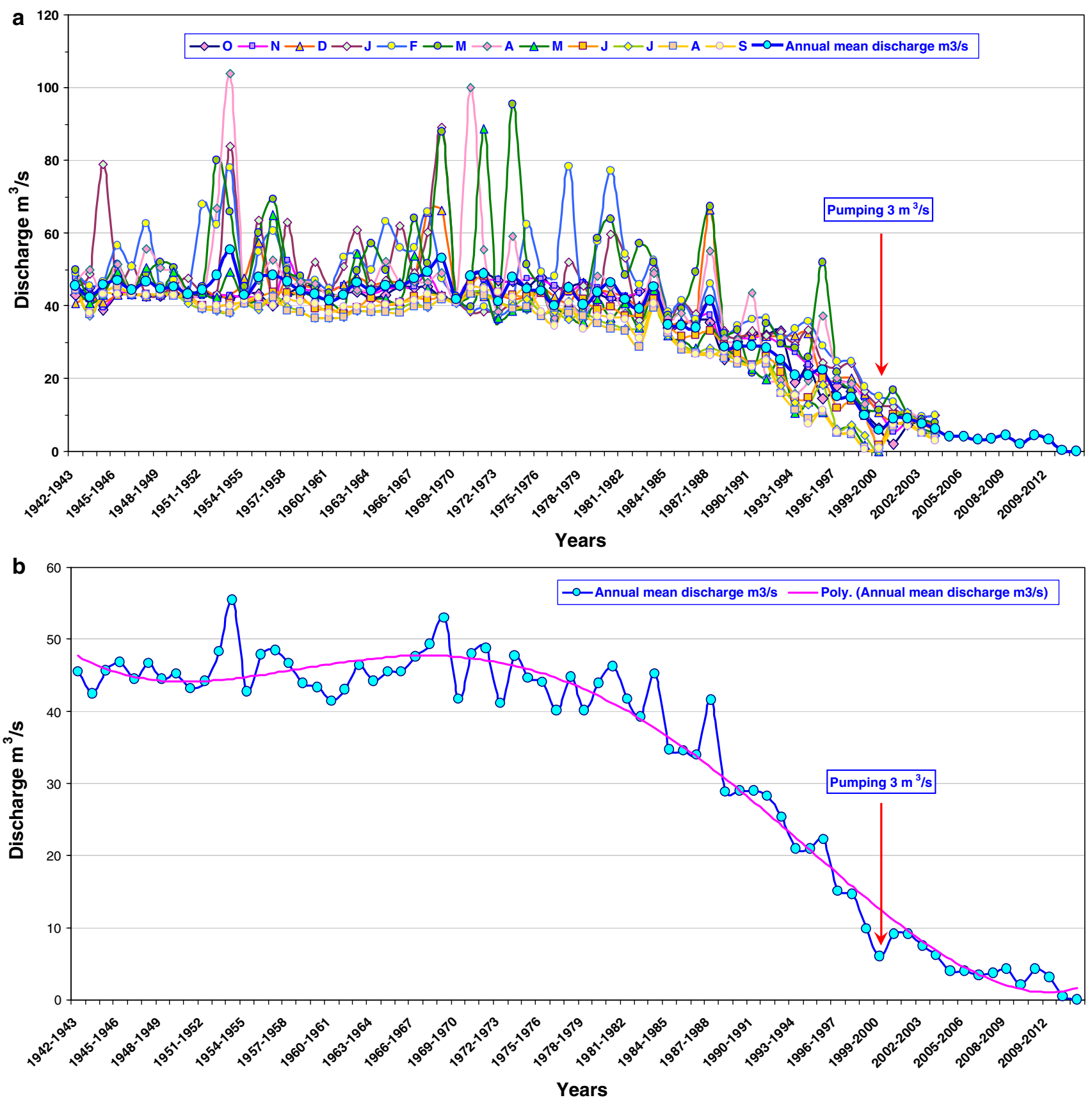

Figure 4. (a) Monthly mean discharge time series and (b) annual mean discharge of Ras El Ain spring.

whereas, during the period 1991-2014, the slope was reduced to 0.78 as shown in the following equation:

Tal Tamer $\left(Q \mathrm{~m}^{3} / \mathrm{s}\right)$ $=0.78 \mathrm{Ras} \operatorname{El} \operatorname{Ain}\left(Q \mathrm{~m}^{3} / \mathrm{s}\right)-0.74$, $R^{2}=0.92$.

The shifting of Ras El Ain discharge value between equation (5) and (6) reflects the deficits due to the overexploitation (figure 6a). Therefore, the deficits computed by these equations are used for the reconstruction of the discharge of Ras El Ain spring. Similarly, this method was used to compute the deficits of Ras El Ain discharge value based on its correlation with $\mathrm{Al}$ Hassakha gauge station (figure 6b).

\subsubsection{Deficit estimation of annual mean discharge in Ras El Ain spring}

The deficit of annual mean discharge of Ras El Ain spring is calculated based on historical relationships with Tal Tamer and Al Hassakha gauge 


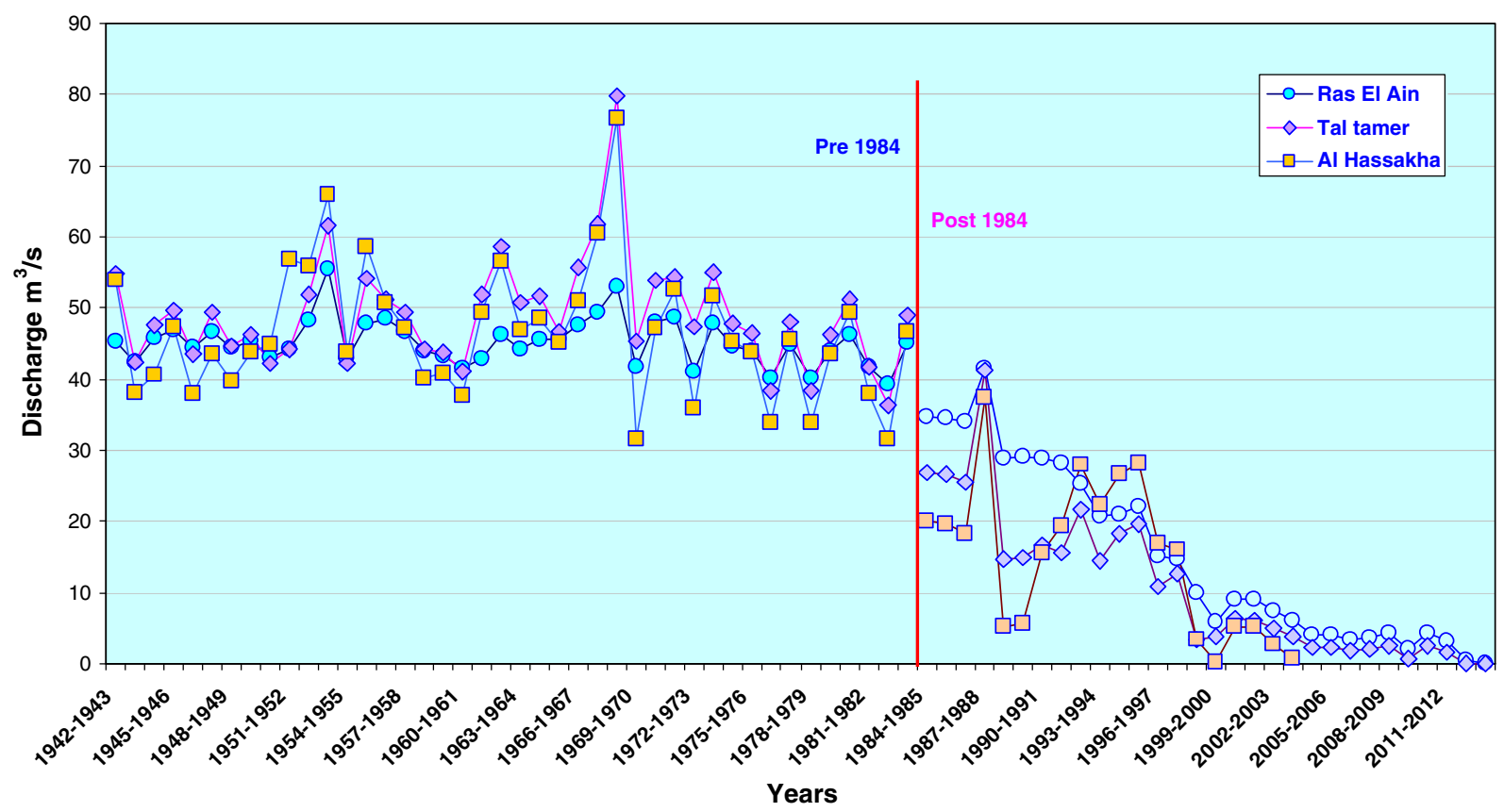

Figure 5. Annual mean discharge at Ras El Ain, Tal Tamer and Al Hassakha gauge stations (pre- and post-1984).

stations (figure 6a, b). Deficit values are estimated as discharge by $\mathrm{m}^{3} / \mathrm{s}$ or million cubic meters (MCM) covering the period from 1991 to 2014 (24 yrs). Annual mean discharge deficit of Ras El Ain calculated by the relationships with Tal Tamer gauge station was estimated by equations ( 5 and 6 ) ( $\left.m=14.35 \mathrm{~m}^{3} / \mathrm{s}\right)$, the confidence level at $95 \%$ of this mean was $\pm 2.52 \mathrm{~m}^{3} / \mathrm{s}$, the standard deviation was $\sigma=5.98 \mathrm{~m}^{3} / \mathrm{s}$, the minimum $=0.59 \mathrm{~m}^{3} / \mathrm{s}$, and the maximum $=21.32 \mathrm{~m}^{3} / \mathrm{s}$. While, annual mean discharge deficit computed by the relationships with Al Hassakha gauge station (figure 6b) was $m=20.26 \mathrm{~m}^{3} / \mathrm{s}$, the confidence level at $95 \%= \pm 2.31 \mathrm{~m}^{3} / \mathrm{s}$, the standard deviation $\sigma=$ $5.47 \mathrm{~m}^{3} / \mathrm{s}$, the minimum $=9.25 \mathrm{~m}^{3} / \mathrm{s}$ and the maximum $=26.53 \mathrm{~m}^{3} / \mathrm{s}($ table 4$)$.

\subsubsection{Reconstructed annual mean discharge of Ras El Ain spring}

The reconstructed annual mean discharge values of Ras El Ain spring are obtained by the addition of measured annual mean discharge and the annual discharge deficit amount computed by the correlation between Ras El Ain with Tal Tamer and Al Hassakha gauge stations (figure 6a, b). It is observed that the discharge deficit of Ras El Ain spring was measured in Al Hassakha after 1984, while it was recorded in Tal Tamer since 1990.
The two reconstructed lines are parallel and have similar variation patterns. However, the reconstructed line by Tal Tamer gauge station is more appropriate for the next statistical analyses step (figure 7).

Table 5 summarizes the annual mean discharge pre-1984 which is ranged from 45.2, 49 and 46.5 $\mathrm{m}^{3} / \mathrm{s}$ while post-1984 it decreases to $9.9,10.8$ and 15.2 (21-34\%) in Ras El Ain, Tal Tamer and $\mathrm{Al}$ Hassakha gauge stations, respectively. The overpumping annual mean deficit of Ras El Ain discharge is between 14.4 and $20.3 \mathrm{~m}^{3} / \mathrm{s}(32-45 \%)$. Whereas, annual mean drought deficit is between 9.7 and $15.7 \mathrm{~m}^{3} / \mathrm{s}(22-35 \%)$.

\subsection{Standardized precipitation (SPI) and discharge (SQI) index}

The long-term fluctuation pattern of annual precipitation and annual mean spring discharge in Ras El Ain show a high deviation, and a trend towards drought occurred during the last three decades. Moreover, the aquifer overexploitation in the catchment areas is an additional factor that leads to further complications, putting the water resources under stress.

Standardized precipitation index (SPI) as defined by McKee et al. (1993), was applied to the annual precipitation time series (1940-1941 to 2007-2008) 

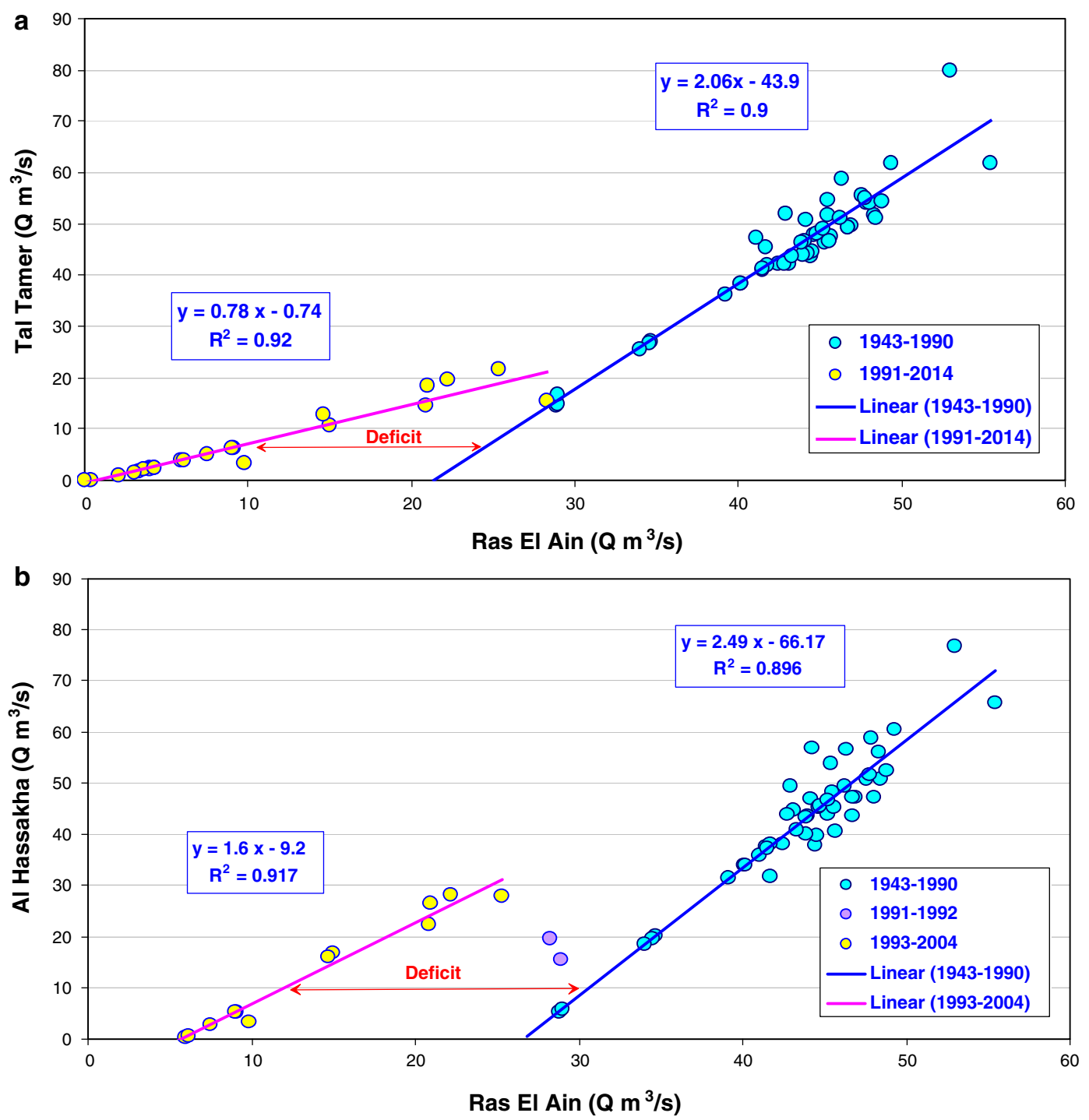

Figure 6. Relationship between annual mean discharges of Ras El Ain spring: (a) Tal Tamer and (b) Al Hassakha gauge stations.

of Ras El Ain meteoric station (figure 8a). The drought event occurrences in the study area with lower than average precipitation of varying severity and scale has been changing during the last century. The drought frequency was 2-4 years during the early years of the century before the 80 's. While after 1988, the droughts frequency increased to 6-7 consecutive years with negative SPI separated by $2-3$ yrs with positive SPI values. Between 1958 and 1961 (figure 8a), four consecutive severe drought years had a deficit ranging from 18 to $34 \%$ and $26 \%$ deficit per year on average. The SPI values decreased to -1.3 indicating severe meteoric drought. Three consecutive moderate to severe drought years (1973-1975) had a deficit of $37 \%$ (SPI $=-1.4$ ), followed by two moderate drought years of $9 \%$ deficit. Two consecutive drought periods were moderate to severe almost occurred during the 4th quarter of the last century. The first one of seven years drought of $18 \%$ deficit per year on average was between 1988 and 1995. Subsequent one was between 1999 and 2003 of five drought years had a maximum deficit reaching $39 \%$ in $1999-2000(\mathrm{SPI}=-1.5)$ and $21 \%$ deficit per year on average. Five-year moving average of SPI illustrates clearly normal fluctuations during the period 1943-1988. Whereas, the decreasing tendency of SPI, demonstrates severe extended drought during the last three decades (figure 8a). 
Table 4. Deficit of annual mean discharge in Ras El Ain calculated by the relationships with Tal Tamer and Al Hassakha gauge stations.

\begin{tabular}{|c|c|c|c|c|}
\hline \multirow{2}{*}{$\begin{array}{l}\text { Deficit } \\
\text { Count ( } 24 \text { yrs) }\end{array}$} & \multicolumn{2}{|c|}{ Tal Tamer } & \multicolumn{2}{|c|}{ Al Hassakha } \\
\hline & $\mathrm{m}^{3} / \mathrm{s}$ & $\mathrm{MCM}$ & $\mathrm{m}^{3} / \mathrm{s}$ & $\mathrm{MCM}$ \\
\hline 1990-1991 & 0.59 & 18.7 & 9.25 & 291.8 \\
\hline 1991-1992 & 0.60 & 19.0 & 9.63 & 303.6 \\
\hline 1992-1993 & 6.58 & 207.5 & 11.41 & 359.8 \\
\hline 1993-1994 & 7.58 & 239.0 & 14.07 & 443.8 \\
\hline 1994-1995 & 9.36 & 295.2 & 14.02 & 442.3 \\
\hline 1995-1996 & 8.70 & 274.2 & 13.26 & 418.2 \\
\hline 1996-1997 & 11.60 & 365.8 & 17.58 & 554.3 \\
\hline 1997-1998 & 12.86 & 405.4 & 17.78 & 560.8 \\
\hline 1998-1999 & 13.14 & 414.3 & 20.68 & 652.2 \\
\hline 1999-2000 & 17.27 & 544.6 & 23.01 & 725.6 \\
\hline 2000-2001 & 15.32 & 483.1 & 21.12 & 666.1 \\
\hline 2001-2002 & 15.36 & 484.5 & 21.16 & 667.4 \\
\hline $2002-2003$ & 16.33 & 514.9 & 22.10 & 696.9 \\
\hline 2003-2004 & 17.15 & 540.8 & 22.89 & 722.0 \\
\hline 2004-2005 & 18.45 & 581.7 & 24.15 & 761.7 \\
\hline 2005-2006 & 18.49 & 583.2 & 24.20 & 763.0 \\
\hline 2006-2007 & 18.89 & 595.6 & 24.58 & 775.1 \\
\hline 2007-2008 & 18.71 & 590.0 & 24.40 & 769.6 \\
\hline 2008-2009 & 18.27 & 576.3 & 23.99 & 756.4 \\
\hline 2009-2010 & 19.64 & 619.4 & 25.31 & 798.1 \\
\hline 2010-2011 & 18.32 & 577.7 & 24.03 & 757.7 \\
\hline 2011-2012 & 19.05 & 600.7 & 24.73 & 780.0 \\
\hline 2012-2013 & 20.94 & 660.5 & 26.31 & 829.7 \\
\hline 2013-2014 & 21.32 & 672.3 & 26.53 & 836.8 \\
\hline Mean & 14.35 & 452.7 & 20.26 & 638.9 \\
\hline Standard deviation & 5.98 & 188.5 & 5.47 & 172.4 \\
\hline Minimum & 0.59 & 18.7 & 9.25 & 291.8 \\
\hline Maximum & 21.32 & 672.3 & 26.53 & 836.8 \\
\hline Confidence level (95\%) & 2.52 & 79.6 & 2.31 & 72.8 \\
\hline
\end{tabular}

Note: Million Cubic Meters (MCM).

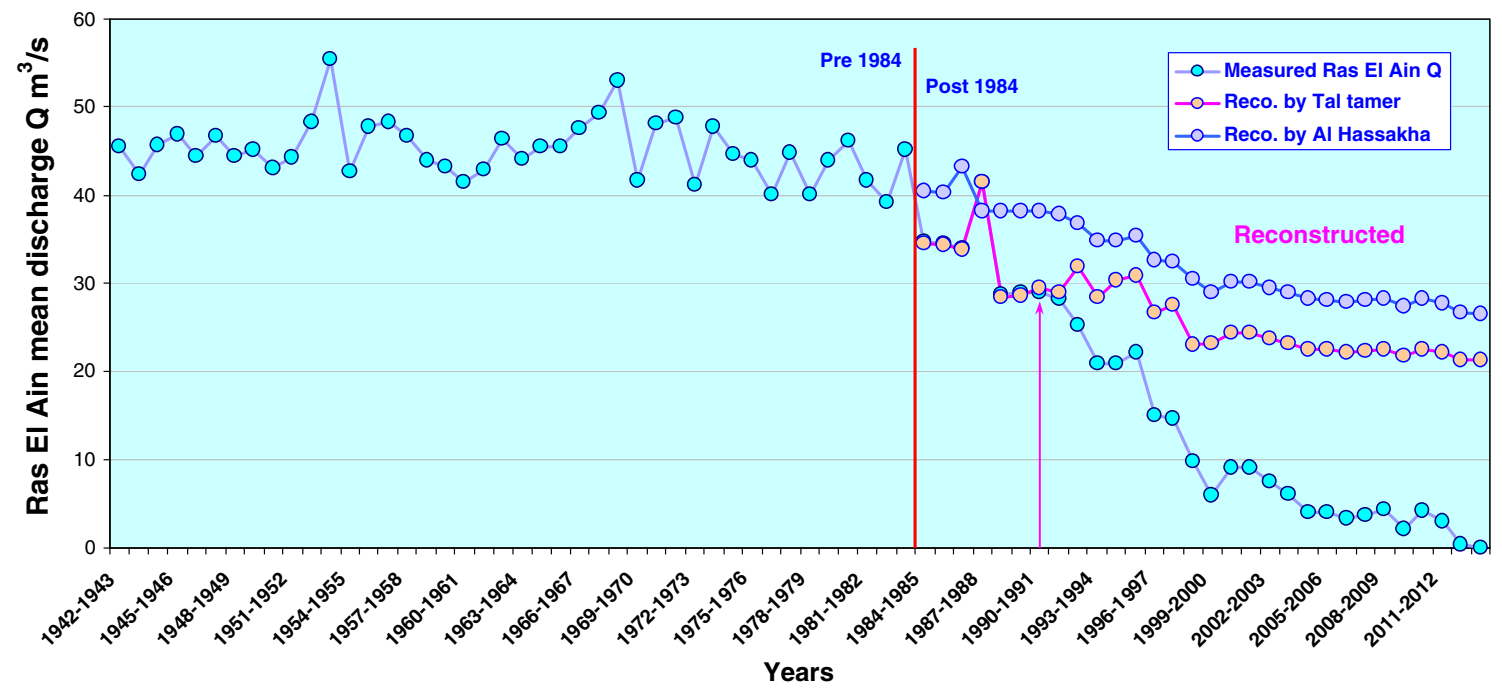

Figure 7. Reconstructed annual mean discharge of Ras El Ain by the relationships with Tal Tamer and Al Hassakha gauge stations. 
Table 5. Annual mean discharge pre- and post-1984 in Ras El Ain, Tal Tamer and Al Hassakha gauge stations, overpumping and drought annual mean deficit of Ras El Ain Spring (1984-2014).

\begin{tabular}{|c|c|c|c|c|c|c|}
\hline \multirow[b]{2}{*}{ Mean $Q\left(\mathrm{~m}^{3} / \mathrm{s}\right)$} & \multirow{2}{*}{$\frac{\text { Pre-84 (42 yrs })}{\left(\mathrm{m}^{3} / \mathrm{s}\right)}$} & \multirow{2}{*}{$\frac{\text { Post- } 84(30 \mathrm{yrs})}{\left(\mathrm{m}^{3} / \mathrm{s}\right)}$} & \multicolumn{2}{|c|}{ Overpum. deficit } & \multicolumn{2}{|c|}{ Drought deficit } \\
\hline & & & $\left(\mathrm{m}^{3} / \mathrm{s}\right)$ & $(\%)^{*}$ & $\left(\mathrm{~m}^{3} / \mathrm{s}\right)$ & $(\%)^{*}$ \\
\hline Ras El Ain & 45.2 & 15.2 & - & - & - & - \\
\hline Tal Tamer & 49.0 & 10.8 & 14.4 & 32 & 15.7 & 35 \\
\hline Al Hassakha & 46.5 & 9.9 & 20.3 & 45 & 9.7 & 22 \\
\hline
\end{tabular}

\%*: Deficit rates are relative to Ras El Ain mean discharge $\left(Q=45.2 \mathrm{~m}^{3} / \mathrm{s}\right)$.
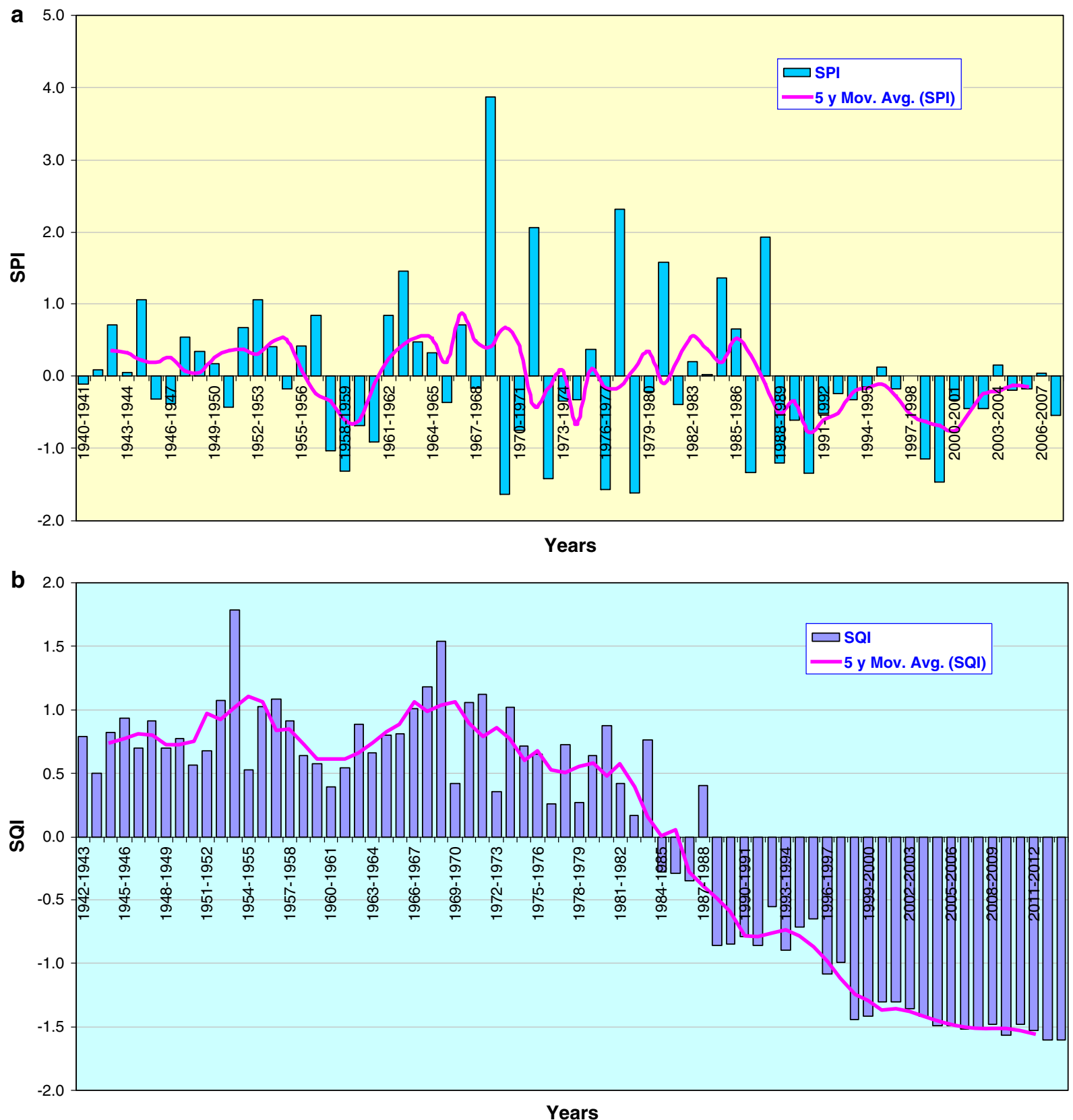

Figure 8. (a) The SPI of annual precipitation and (b) the SQI of reconstructed annual mean discharge of Ras El Ain spring. 
Standardized discharge index (SQI) was applied to the annual mean discharge time series (19421943 to 2013-2014) of Ras El Ain spring (figure $8 \mathrm{~b}$ ). It is worth to mention that the annual mean discharge time series of Ras El Ain spring was reconstructed based on the estimated discharge deficit due to overexploitation using equations (5 and 6) for the post-1990 period. The SQI plot shows that the early years of the century are characterized by high flow with positive SQI values. The four years drought during the 60's has a slight effect on the discharge index. The lowest SQI value was measured in 1960 (0.4). The index increased to a maximum value of 1.54 in 1968-1969. While, it decreased gradually to a negative value post-1984 and reached -1 in 1997-1998, and -2 in 2004-2005 that exhibit extreme hydrologic droughts. Fiveyr moving average of SQI shows clearly normal variations during the period from 1943 to 1983. While, after 1984 the decreasing SQI to negative values express severe extended hydrologic drought covering the last three decades (figure $8 \mathrm{~b}$ ). It is observed that the SQI variations are comparable to the SPI pattern pre-1984. Consequently, the drought effects are considered as the main factor controlling the discharge index of the spring pre1984. However, the SQI values are disproportional with that of SPI and the divergence was observed since 1975. It is clear that after 1990, the fluctuations of SQI are deviating from SPI pattern. It is believed that there are considerable anthropogenic effects, which aggravate the hydrologic droughts.

\subsection{Cumulative drought analyses}

\subsubsection{Standardized precipitation (SPI10) and discharge (SQI10) index}

Shallow groundwater and karstic springs are generally very sensitive and vulnerable to the extended and severe drought (Fiorillo 2009; Bloomfield and Marchant 2013). In one hand, the groundwater level is affected by drought duration and severity causing a reduction in recent groundwater recharge. In another hand, the groundwater quality can be affected in a negative manner. Therefore, agricultural drought put the groundwater under stress to respond the increased demand for irrigation water. Overexploitation is further a complicating factor, causing deterioration of groundwater quantity and quality.
The application of SPI10 on the annual precipitation in Ras El Ain station for 68 yrs record (1940-2008) illustrate very well the pattern of wet and drought years and its possible impact on spring discharge. From 1950 to 1959, the SPI10 has positive values indicating wet period with above-average precipitation. From 1960 to 1968 , the SPI10 shows negative values $(0$ to -0.3$)$ corresponding to moderate drought. The following period from 1968 to 1978 of 10 years, is very wet with positive SPI10 values reaching +2 . The subsequent drought was between 1979 and 1983 produced negative SPI10 values of moderate drought. This drought is followed by seven wet years (19841990). Consecutive drought from 1990 to 1997, of SPI10, decreased abruptly below -1.5 (figure 9a), which exhibit extremely extended drought and can negatively affect the recent groundwater recharge. The 5-yr moving average has decreasing tendency expressing severe drought particularly after 1997.

Based on the annual mean discharge time series of Ras El Ain spring for 72-yr record (1943-2014), the cumulative discharge index computed over 10 years (SQI10), demonstrates very well, the pattern of discharge variations. From 1970 to 1989, the SQI10 has positive values indicating wet period with high discharge above average. The moderate drought during the 60's has a relatively slight decline of the SQI10 from 0.94 to 0.73 indicating the huge storage capacity of the aquifer reservoir system. The SQI10 decreased moderately during the 80's and has negative values since 1989-1990. During the 90 's, the cumulative index decreased gradually from 0 to -1 indicating moderate to severe hydrologic drought. Between 2000 and 2006, SQI10 was ranged from -1 to -1.5 revealing severe drought, after 2007 it dropped below -1.5 exhibiting extreme hydrologic drought affecting the spring discharge. However, the 5-yr moving average illustrates very well the pattern of decreasing tendency expressing drought period effect starting from 1990 and transformed to extreme hydrologic drought after 2007 where SQI10 decreased below -1.5 (figure 9b).

\subsubsection{SPI10 and SQI10 relationship}

The relationship between cumulative standardized precipitation (SPI10) and discharge (SQI10) index computed over 10 years demonstrates very well the hydrologic history of the karst reservoir system related to precipitation pattern and anthropogenic 

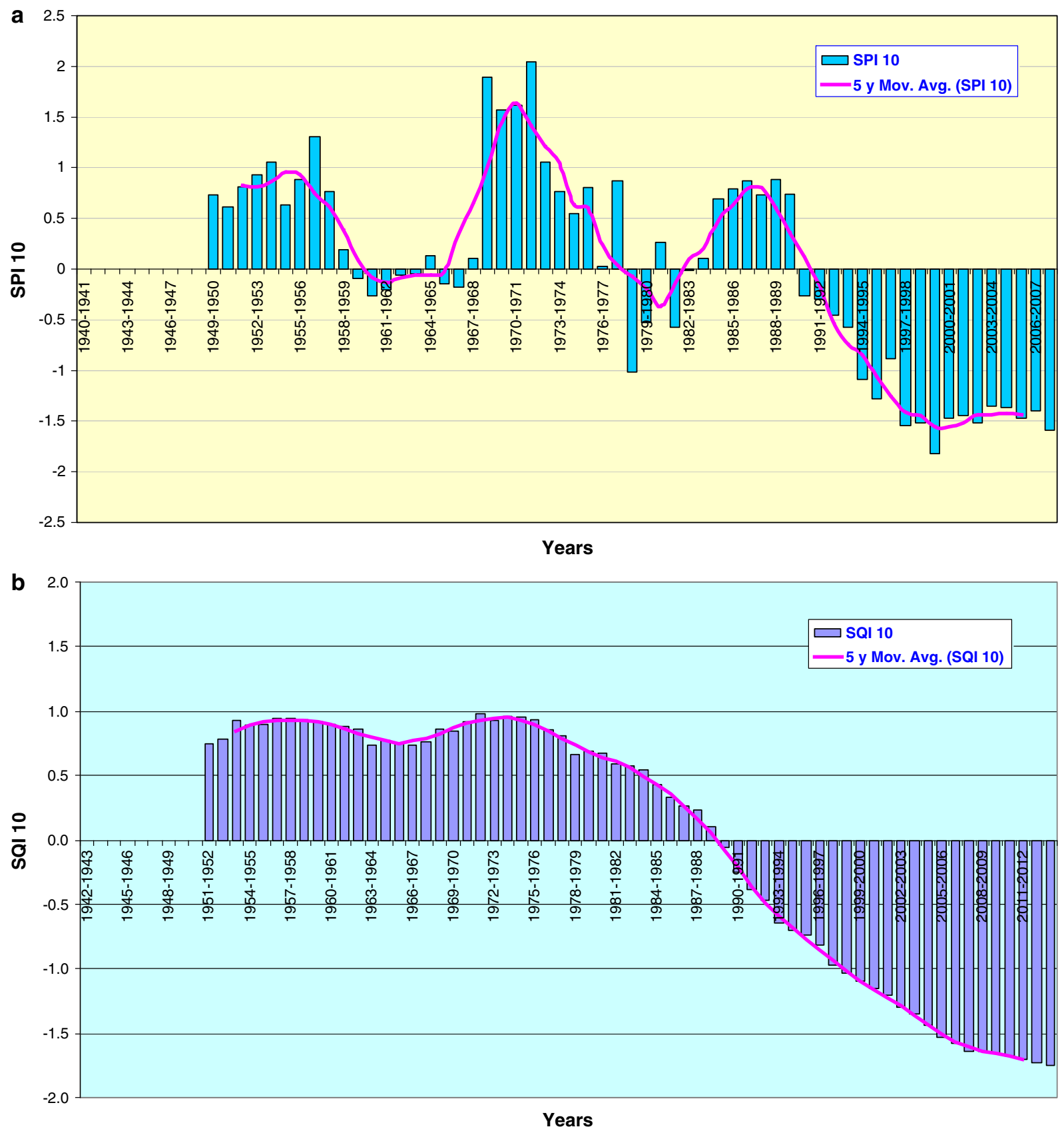

Figure 9. (a) SPI10 of annual precipitation and (b) SQI10 of reconstructed annual mean discharge of Ras El Ain.

effects such as the overexploitation of groundwater. The hydrologic history of the karst system discharge can be divided into the following periods (figure 10):

- Wet period (1951-1984) with positive SPI10 and SQI10 characterized by high precipitation and spring discharge. The SPI10 and SQI10 correlation exhibits decreasing trend as follows: $\mathrm{SQI10}=0.094 \mathrm{SPI} 10+0.78\left(R^{2}=0.315\right)$ with relatively low decreasing rate SPI10:SQI10 equal to 1:0.094. Thus, the spring system has a huge groundwater reservoir capacity with a slight effect of precipitation fluctuations. This period was clearly conceived under natural conditions without any anthropogenic effects.

- Overexploitation period (1985-1989) distinguished by a decreasing SQI10 without notable variations of SPI10. This period corresponds to the expanding of groundwater intensive pumping for irrigation projects in the catchment areas of the system.

- Drought period (1990-2000) with a negative SPI10 and SQI10 characterized by the effect of 


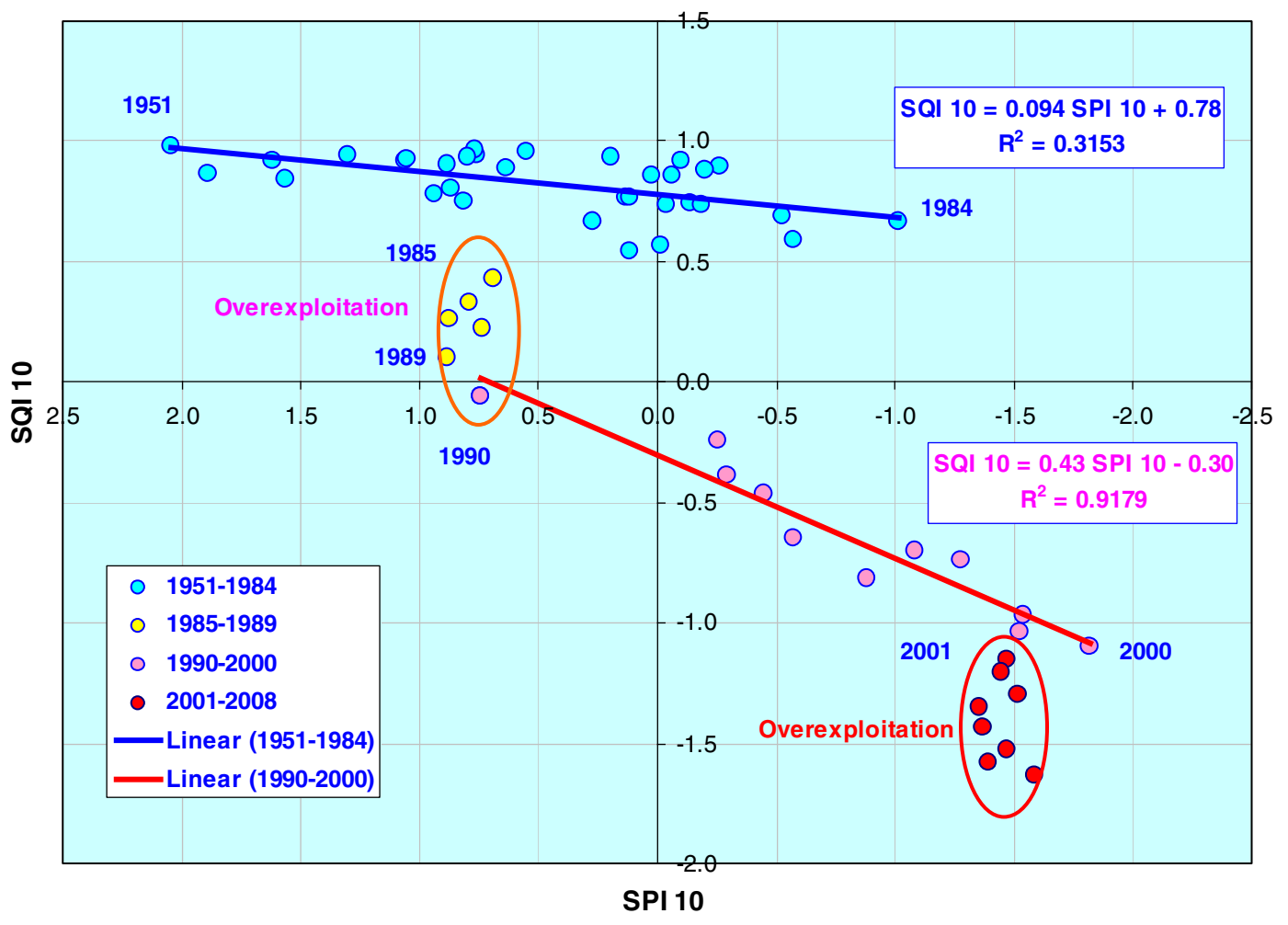

Figure 10. SPI10 and SQI10 relationship of Ras El Ain spring.

severe and extended droughts. The relationship between SPI10 and SQI10 shows that decreasing trend is expressed by the following equation: SQI10 $=0.43$ SPI10 $-0.3\left(R^{2}=918\right)$ with SPI10: SQI10 equal to 1:0.43 indicating strong effect of meteorological and hydrologic drought on the spring behaviour. Consequently, the precipitation and flow regimes are deficient, especially when the SPI10 and SQI10 values are declining below -1 to -1.5 . The response of the karst system to the precipitation signal was changed and the spring behaviour has been modified due to consecutive overexploitation periods.

- Severe overexploitation period (2001-2008) is differentiated by a decreasing SQI10 without or little variations of SPI10 (figure 10). This period is related to the second phase of groundwater intensive pumping for irrigation purposes. Consequently, the second overexploitation period is completely catastrophic causing the drying up of one of the major karst springs in the world.

\subsection{Precipitation and discharge decreasing trends}

\subsubsection{Decreasing precipitation DPI and discharge $D Q I \%$ index}

The assessment of a climate trend at the regional and long-term scale was performed by defining the indices representative of the annual anomalies with respect to the mean value, which minimized variations due to local and seasonal factors. To obtain such an index for precipitation, the time series of annual precipitation DPI\% and the annual mean discharge DQI\% were first analyzed with a least squares linear regression approach (figure 11a, b).

Decreasing precipitation index (DPI) was applied on the time series of annual precipitation of Ras El Ain meteoric station (1940-2008) for 68 yrs. While, decreasing discharge index (DQI) was applied for 44 yrs (1940-1884), this period was clearly considered under natural conditions prior to any anthropogenic effects. The long-term declining linear trend over the observed time series of the DQI was generally in accordance with the declining linear trend of the DPI. This analysis showed a general decreasing linear trend for the DPI with annual rate of $-0.268 \%$, with respect to the mean value $(296.9 \mathrm{~mm} / \mathrm{y})$ as follows:

$$
\mathrm{DPI} \%=-0.268 \times \text { Year }+9.24
$$

where Year is the observation number counting from the beginning of the time series.

Whereas, the decreasing linear trend for the DQI with an annual rate of $-0.105 \%$, relative to the mean value $\left(45.18 \mathrm{~m}^{3} / \mathrm{s}\right)$ as in the following equation: 

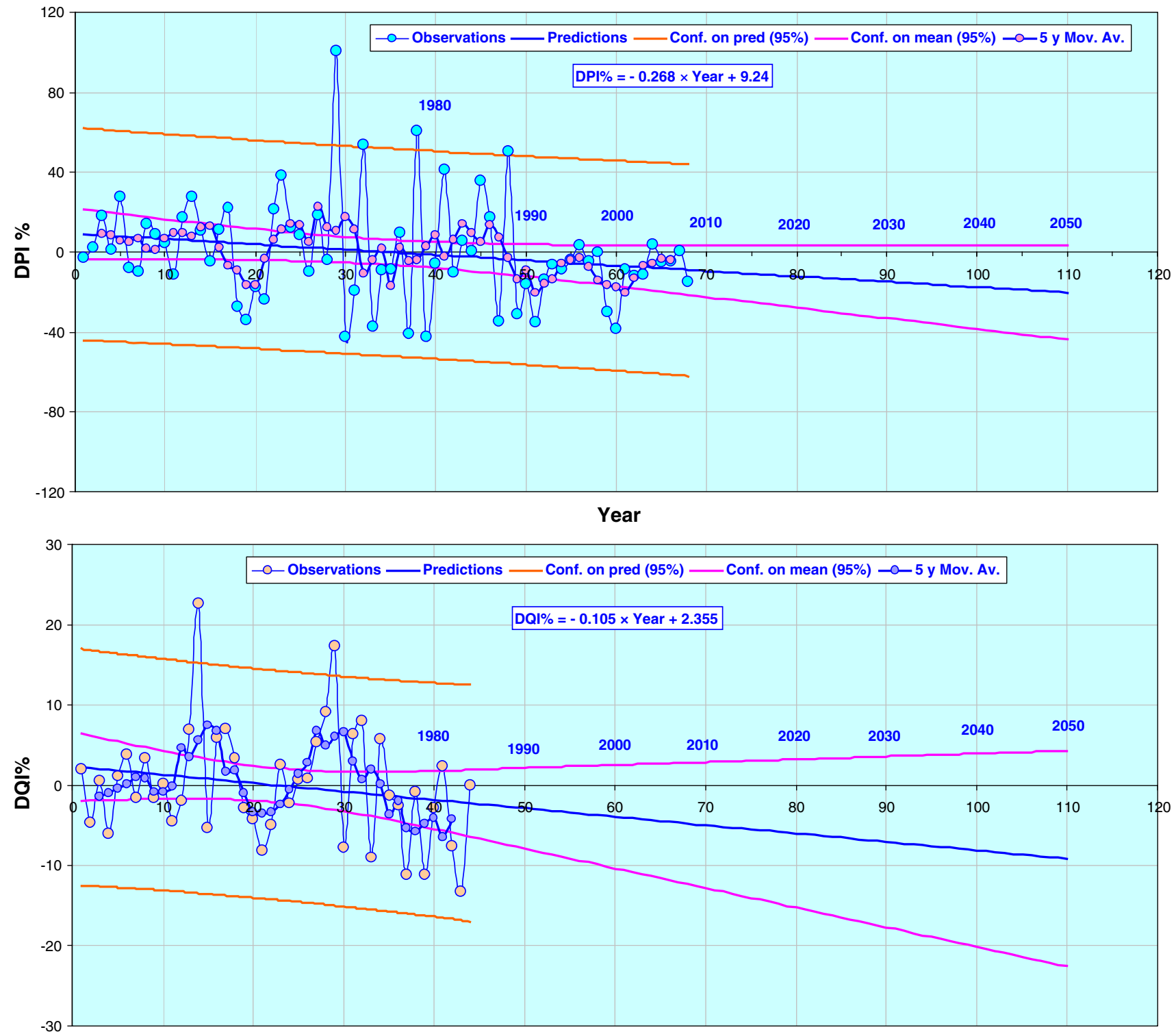

Year

Figure 11. Decreasing precipitation (DPI\%) and discharge (DQI\%) index, prediction, confidence limit at CL 95\%, and 5 yr moving average.

$$
\mathrm{DQI} \%=-0.105 \times \text { Year }+2.355
$$

Moreover, the 5-yr moving average pattern relative to the normal value (mean value of the observed time series) exhibits a complex cyclical dynamic (figure 11a, b). During the 50's and the 70 's, two phases were identified, which are characterized by values above the normal, and one phase below the normal value was recognized for the period 1959-1964 with moderate drought. Between 1975 and 1984, the 5-yr moving average of precipitation index shows an increasing tendency, while, that of discharge index demonstrates a decreasing one. Thus, the divergence between the two indices indicates clearly that the anthropogenic effect on the spring discharge by overpumping was started in 1975.

The prediction and confidence limit at CL 95\% on the mean of precipitation and discharge values were carried out using XLSTAT for the year 2050 (table 6). The theoretical model provides an assumption of the discharge mean values of the Ras El Ain spring without or with minimum anthropogenic effects on the catchment areas as pre-1984.

The results of this model show that in 2050, the mean spring discharge will be $40.9 \mathrm{~m}^{3} / \mathrm{s}$ and ranging between 34.7 and $47 \mathrm{~m}^{3} / \mathrm{s}$ at $95 \% \mathrm{CL}$ (hypothesis 1); whereas, this mean will be out of this range with $5 \%$ probability (hypothesis 2 ). 
Table 6. Decreasing precipitation (DPI\%) and discharge (DQI\%) index, prediction and confidence limit at CL $95 \%$.

\begin{tabular}{|c|c|c|c|c|c|c|c|c|}
\hline & \multirow[b]{2}{*}{ DPI $\%$} & \multicolumn{3}{|c|}{ Ras El Ain $P$ mm (68 yrs) } & \multirow[b]{2}{*}{ DQI\% } & \multicolumn{3}{|c|}{ Ras El Ain $Q \mathrm{~m}^{3} / \mathrm{s}(44 \mathrm{yrs})$} \\
\hline & & Prediction & LL $95 \%$ & UL $95 \%$ & & Prediction & LL $95 \%$ & UL $95 \%$ \\
\hline Mean & 0 & 296.9 & 278.1 & 315.7 & 0 & 45.2 & 44.2 & 46.2 \\
\hline 1989-1990 & -4.2 & 284.6 & 260.9 & 308.3 & -2.9 & 43.8 & 41.6 & 46.1 \\
\hline 1999-2000 & -6.8 & 276.6 & 246.2 & 307.1 & -3.9 & 43.3 & 40.4 & 46.3 \\
\hline 2009-2010 & -9.5 & 268.7 & 230.3 & 307.0 & -5.0 & 42.8 & 39.3 & 46.4 \\
\hline 2019-2020 & -12.2 & 260.7 & 214.3 & 307.2 & -6.0 & 42.4 & 38.1 & 46.6 \\
\hline 2029-2030 & -14.9 & 252.8 & 198.2 & 307.3 & -7.1 & 41.9 & 37.0 & 46.7 \\
\hline 2039-2040 & -17.5 & 244.8 & 182.2 & 307.5 & -8.1 & 41.4 & 35.9 & 46.9 \\
\hline 2049-2050 & -20.2 & 236.9 & 166.1 & 307.6 & -9.2 & 40.9 & 34.7 & 47.0 \\
\hline
\end{tabular}

Generally, the results reveal that precipitation will decrease of DPI $=-20.2 \%$ with a decline in the discharge of DQI $=-9.2 \%$ by 2050 (table 5 ; figure $11 \mathrm{a}, \mathrm{b})$. Consequently, the declining discharge due to climatic variation under natural conditions as pre-1984 was about $10 \%$. Whereas, the catastrophic drying up of the spring was probably the consequence of the anthropogenic effects.

\section{Conclusions}

Cumulative drought analyses reveal the following conclusions:

1. Annual mean precipitation over 30 yrs variations of Ras El Ain and Tal Tamer meteoric stations demonstrate a decreasing trend of about $-0.86 \mathrm{~mm}$ per year.

2. The annual mean deficit of Ras El Ain spring discharge due to overpumping was estimated between 14.4 and $20.3 \mathrm{~m}^{3} / \mathrm{s}(32-45 \%)$, whereas, the deficit caused by drought was between 9.7 and $15.7 \mathrm{~m}^{3} / \mathrm{s}(22-35 \%)$ on average during the last 30 yrs.

3. The 5-yr moving averages of SPI and SQI delineate very well the drought periods and exhibit clear decreasing of precipitation and spring discharge over the last three decades.

4. The cumulative drought using SPI10 and SQI10 shows that the time series can be divided as follows:

- Wet period (1943-1984) with positive SPI10 and SQI10 is characterized by high precipitation and spring discharge without any anthropogenic effects.

- Overexploitation period (1985-1989) is distinguished by a decreasing SQI10 without any variations of SPI10. This period corresponds to the intensive pumping of the groundwater for irrigation purposes in the catchment area.

- Drought period (1990-2000) with negative index values is marked by the hydrologic drought effect on the spring behaviour due to overexploitation. The response of the karst system to the precipitation signal has been changed.

- Overexploitation period (2001-2008) is recognized by a decreasing SQI10 without or slight variations of SPI10. This period is related to the second phase of intensive groundwater pumping. Consequently, the second overexploitation period is completely catastrophic causing the drying up of one of the major karst springs in the world.

5. The decreasing trends analysis using DPI and DQI showed annual decreasing rates relative to the mean values of $-0.268 \%$ and of $-0.105 \%$, respectively.

6. Based on the analyzed precipitation and discharge data, if the similar trends continue as pre-1984, the precipitation will be decreased of about DPI $=-20.2 \%$ and the discharge will decline of about DQI $=-9.2 \%$ by 2050 .

7. The divergence between DPI and DQI during the 70s indicates clearly that the anthropogenic effect on the spring discharge by overpumping started in 1975, followed by severe overpumping (1985-1989) and finally, the dramatic overexploitation period of 2001-2008.

Consequently, the declining of discharge due to climatic variation under natural conditions was about $10 \%$. Whereas, the catastrophic drying up of Ras El Ain spring was probably the result of the anthropogenic effects. The cumulative drought analyses have provided useful information for the development of sustainable water resources 
management plan for groundwater protection, restore the groundwater reservoir, reduce overexploitation, and long-terms drought risks connected to climate change.

\section{Acknowledgements}

The authors would like to gratefully acknowledge Prof. I Othman, General Director of Atomic Energy Commission of Syria (AECS), for his guidance and support. Thanks are due to Dr S Ahmad, General Director of General Commission for Water Resources (GCWR), Dr B Kamal Addin, Deputy Director of (GCWR) and Dr S Obeid, Director of Water Resources Information Center (WRIC) for the providing the hydrological data. The authors would like to thank Associate Editor of JESS Prof. Subimal Ghosh and reviewers for their constructive and valuable comments and suggestions. Finally, thanks to the colleagues in Geology Department (AECS).

\section{References}

Abou Zakhem B and Kattaa B 2016a Cumulative drought effect on Figeh karstic spring discharge (Damascus basin, Syria); Environ. Earth Sci., doi: 10.1007/ s12665-015-5013-3.

Abou Zakhem B and Kattaa B 2016b Investigation of hydrological drought using Cumulative Standardized Precipitation Index (SPI 30) in the eastern Mediterranean region (Damascus, Syria); J. Earth Syst. Sci., doi: 10. 1007/s12040-016-0703-0.

ACSAD, GDTKB and GCHS 2003 (Arab Center for the Studies of Arid Zones and Dry Lands; General Directorate for Tigris and Khabour Basins; General Corporation for Hydrological Studies) 2003 Project of Preparation of a Database and a Mathematical Model for the Northern Part of the Khabour Basin; In: The Mathematical Model (General Report), Damascus.

AL-Charideh A and Abou Zakhem B 2009 Geochemical and isotopic characterization of groundwater from the Paleogene limestone aquifer of the Upper Jezireh, Syria; Environ. Earth Sci. 59 1065-1078.

Bloomfield J P and Marchant B P 2013 Analysis of groundwater drought building on the standardized precipitation index approach; Hydrol. Earth Syst. Sci. 17 4769-4787.

Bonaccorso B, Bordi I, Cancelliere A, Rossi G and Sutera A 2003 Spatial variability of drought: An analysis of SPI in Sicily; Water Resour. Manag. 17 273-296.

Burdon D and Safadi C 1963 Ras El-Ain (the great karst springs of Mesopotamia); J. Hydrol. 1(1) 58-95.

Cancelliere A, Di Mauro G, Bonaccorso B and Rossi G 2005 Stochastic forecasting of Standardized Precipitation Index; Proceedings of XXXI IAHR Congress on Water
Engineering for the future: Choice and Challenges, Seoul, Korea, 11-16 September 2005, pp. 3252-3260.

Cancelliere A, Bonaccorso B and Di Mauro G 2006 A nonparametric approach for drought forecasting through the Standardized Precipitation Index; Giornata di Studio: Metodi Statistici e Matematici per l'Analisi delle Serie Idrologiche-Viterbo 2006.

Chen Z, Grasby S E and Osadetz K G 2004 Relation between climate variability and groundwater levels in the upper carbonate aquifer, southern Manitoba, Canada; J. Hydrol. $29043-62$.

Dai A 2011 Drought under global warming: A review; Wiley Interdiscip. Rev. Clim. Change 2(1) 45-65, doi: 10.1002/ wcc. 81.

Edwards D C and McKee T B 1997 Characteristics of 20th century drought in the United States at multiple time scales; Climatology Report Number 97-2, Colorado State University, Fort Collins, Colorado.

El-Hakim M and Bakalowicz M 2007 Significance and origin of very large regulating power of some karst aquifers in the Middle East. Implication on karst aquifer classification; J. Hydrol. 333 329-339.

FAO 2009 (Food and Agriculture Organization of the United Nations) Irrigation in the Middle East Region in Figures, aquastat survey 2008; In FAO Reports 34, Rome.

Fiorillo F, Esposito L and Guadagno F M 2007 Analyses and forecast of the water resource in an ultra-centenarian spring discharge series from Serino (southern Italy); $J$. Hydrol. 36 125-138.

Fiorillo F 2009 Spring hydrographs as indicators of droughts in a karst environment; J. Hydrol. 373 290-301.

Fiorillo F and Guadagno F M 2010 Karst spring discharges analysis in relation to drought periods, using the SPI; Water Resour. Manag. 24 1867-1884.

Fiorillo F and Guadagno F M 2012 Long karst spring discharge time series and droughts occurrence in southern Italy; Environ. Earth Sci. 65(8) 2273-2283.

Fiorillo F, Esposito L, Petitta M, Preziosi E and Tallini M 2014 Long-term trend and fluctuations of karst spring discharge in a Mediterranean area (central-southern Italy); Environ. Earth Sci., doi: 10.1007/s12665-014-3946-6.

Guttman N B 1999 Accepting the Standardized Precipitation Index: A calculating algorithm; J. Am. Water Resour. Assoc. 35(2) 311-323.

Hajispyrou E, Pashardes P, Photiou C, Rostan di N and Tsiourtis N X 2007 Application of the drought management guidelines in Cyprus [Part 2. Examples of application]; In: Drought management guidelines technical annex (eds) Iglesias A, Moneo M and López-Francos A, Zaragoza: CIHEAM/EC MEDA Water, pp. 215-244 (Options Méditerranéennes: Série B, Etudes et Recherches n. 58).

Hamdy A 2004 Drought preparedness and mitigation in the Mediterranean region; In: Water Management for Drought Mitigation in the Mediterranean, Centre International de Hautes Etudes Agronomiques Méditerranéennes (CIHEAM), Options Méditerranéennes, Série B, N. 47, p. 328.

Hayes M J, Svoboda M, Le Comte D, Redmond K T and Pasteris P 2005 Drought monitoring: New tools for the 21st century; In: Drought and watercrisis (ed.) Wilhite D A, Taylor and Francis, Boca Rateon, Florida. 
Heim R R 2000 Drought indices: A review; In: Drought: A Global Assessment (ed.) Wilhite D A, Routledge, London and New York.

Hole F 2009 Drivers of unsustainable land use in the semiarid Khabur River Basin, Syria; Geogr. Res. 47(1) 1-14.

IPCC 2007 Regional Climate Projections. Climate Change 2007: The Physical Science Basis; Contribution to Working Group I and to AR4 (Fourth Assessment Report of the Intergovernmental Panel on Climate Change) (eds) Solomon S, Qin D, Manning M, Chen Z, Marquis M, Averyt K B, Tignor M and Miller H L, Cambridge University Press, Cambridge, UK, pp. 847-940.

Kattan Z 2001 Use of hydrochemistry and environmental isotopes for evaluation of groundwater in the Paleogene limestone aquifer of the Ras El-Ain area (Syrian Jezireh); J. Environ. Geol. 41 128-144.

Łabedzki L and Bak B 2014 Meteorological and agricultural drought indices used in drought monitoring in Poland: A review; Meteorol. Hydrol. Water Manag. 2(2) 1-12.

Loukas A and Vasiliades L 2004 Probabilistic analysis of drought spatiotemporal characteristics in Thessaly region, Greece; Nat. Hazards Earth Syst. Sci. 4 719-731.

McKee T B, Doesken N J and Kleist J 1993 The relationship of drought frequency and duration to time scales; In: Proceedings of the 8th Conference on Applied Climatology, Boston, MA, USA, Am. Meteorol. Soc. 17(22) 179-183.

McKee T B, Doesken N J and Kleist J 1995 Drought monitoring with multiple time scales, Preprints, 9th Conference on Applied Climatology, Dallas, TX, Am. Meteor. Soc., pp. 233-236.

MED WS and D WG 2007 (Mediterranean Water Scarcity and Drought, Working Group): Technical report on water scarcity and drought management in the Mediterranean and the Water Framework Directive (Tec. Rep. 0092007). EUWI/WFD Joint process, April 2007, http:// www.emwis.net/topics/WaterScarcity.

Michaelides S and Pashiardis S 2008 Monitoring drought in Cyprus during the 2007-2008 hydrometeorological year by using the Standardized Precipitation Index (SPI); Eur. Water Publ. 23/24 123-131.

Mishra A K and Singh V P 2010 A review of drought concepts; J. Hydrol. 391(1-2) 202-216, doi: 10.1016/j. jhydrol.2011.03.049.

Pashiardis S and Michaelides S 2008 Implementation of the Standardized Precipitation Index (SPI) and the Reconnaissance Drought Index (RDI) for Regional Drought Assessment: A case study for Cyprus; Eur. Water Publ. 23/24 57-65.

Ragab R and Hamdy A 2004 Water management strategies to combat drought in the semiarid regions; In: Water Management for Drought Mitigation in the Mediterranean, Centre International de Hautes Etudes Agronomiques Méditerranéennes (CIHEAM), Options Méditerranéennes, Série B, N. 47, p. 328.

Rossi G and Cancelliere A 2002 Early warning of drought: Development of a drought bulletin for Sicily; In: Pro- ceedings of 2nd International Conference "New trends in Water and Environmental Engineering for Safety and Life: Eco-compatible Solutions for Aquatic Environments", Capri, Italy, June 24-28, 2002, pp. 1-12.

Sheffield J and Wood E F 2008 Global trends and variability in soil moisture and drought characteristics, 1950-2000, from observation-driven simulations of the terrestrial hydrologic cycle; J. Climate 21 432-458.

Sheffield J, Andreadis K M, Wood E F and Lettenmaier D P 2009 Global and continental drought in the second half of the 20th century: Severity-area-duration analysis and temporal variability of large-scale events; J. Climate $\mathbf{2 2}$ 1962-1981.

Shulka S and Wood A W 2008 Use of a standardized runoff index for characterizing hydrologic drought; Geophys. Res. Lett. 35 L02405, doi: 10.1029/2007GL032487.

Smith B A and Hunt B B 2010 A comparison of the 1950s drought of record and the 2009 drought, Barton Springs segment of the Edwards Aquifer, central Texas; Gulf Coast Assoc. Geol. Soc. Trans. 60 611-622.

Törnros T and Menzel L 2014 Addressing drought conditions under current and future climates in the Jordan River region; Hydrol. Earth Syst. Sci. 18 305-318.

Turgu E 2008 Using Standardized Precipitation Index for Monitoring Drought and Analyzing Drought. BALWOIS 2008 - Ohrid, Republic of Macedonia - 27, 31 May 2008.

UNDP-FAO 1966 Etudes des Ressources en Eaux Souterraines (République Arabe Syrienne); Rapport Final, FAO/SF: 17/SYR, p. 267.

UN-ESCWA and BGR 2013 (United Nations Economic and Social Commission for Western Asia; Bundesanstalt für Geowissenschaften und Rohstoffe) 2013 Inventory of Shared Water Resources in western Asia; Beirut.

Vicente-Serrano S M, Gonzalez-Hidalgo J C, De Luis M and Raventos J 2004 Drought patterns in the Mediterranean area: The Valencia region (eastern Spain); Climate Res. 26 5-15.

Vicente-Serrano S M and López-Moreno J I 2005 Hydrological response to different time scale of climatological drought: An evaluation of the Standardized Precipitation Index in a mountainous Mediterranean basin; Hydrol. Earth Syst. Sci. 9 523-533.

Wilhite D A and Glantz M H 1987 Understanding the drought phenomenon: The role of definition; In: Planning for Drough (eds) Wilhite D A, Eastrling W E and Wood D A, Vestview Press, Boulder, CO, pp. 11-27.

WMO 2012 Standardized Precipitation Index User Guide (eds) Svoboda M, Hayes M and Wood D A, WMO, Geneva, Switzerland.

Zaitchik B, Smith R and Hole F 2002 Spatial analysis of agricultural land use changes in the Khabour river basin of northeastern Syria; In: Land Satellite Information IV: FIEOS, Denver, Colorado.

Zurek R 2007 The basic paths of energy flow and matter transformations in a lowland dam reservoir ecosystem; Oceanol. Hydrobiol. Stud. XXXVI(2) 5-147. 